\title{
Uluslararası Politik Ekonomi Açısından Dördüncü Sanayi- Endüstri Devrimi’nin Etkileri ve Türkiye
}

\author{
The Effects of Fourth Industrial Revolution with respect to \\ International Political Economy and Turkey
}

\author{
Mehmet ÖZKAN \\ $\operatorname{Arzu} \mathrm{AL}^{* *}$ \\ Serkan YAVUZ ${ }^{* * *}$
}

Öz

18. yüzyılda buharlı makinaların icat edilmesi sonucunda ortaya çıkan Birinci Sanayi Devrimi ile birlikte bilimsel çalışmaların hızlanması teknolojik gelişmelerinde hızlanmasına neden olmuştur. $\mathrm{Bu}$ durum ise 2000'li yıllara girilirken çeşitli aşamalardan geçen Sanayi Devrimlerinden sonuncusu olan Dördüncü Sanayi Devrimi’ni ortaya çıkarmıştır. Endüstri 4.0 olarak da adlandırılan bu dönemi diğer sanayi devrimlerinden ayıran en önemli özellik ise yaşanan teknolojik gelişmelerin çok daha hızlı ilerlemesidir. Ayrıca "Endüstri 4.0" ya da "Sanayi 4.0" dönemi olarak da adlandırılan Dördüncü Sanayi Devrimi; devletlerde, şirketlerde ve hatta toplumun tüm katmanlarında ciddi paradigma değişikliklerine neden olmaktadır. Üretim; çeşitli teknolojilerin etkileşimi ile yapılmakta ve üretimde otomasyon sistemi her geçen gün gelişmektedir. Bu otomasyon "siber fiziksel sistemler", "nesnelerin interneti" ve "hizmetlerin interneti" kavramları ile sağlanmakta ve bu durumun sonucunda üretimde insan emeğine olan ihtiyaç her geçen gün azalmaktadır. Üretimde giderek yaygınlaşan otomasyon ile birlikte insan emeğine olan ihtiyacın giderek azalması ise uluslararası politik ekonomi çerçevesinde değerlendirilmesi gereken bir konu olarak ortaya çıkmıştır. Çünkü ucuz işgücü sayesinde doğrudan yabancı sermaye yatırımlarını ülkelerine çeken doğu ülkelerinin bu yatırımların geri çekilmesi durumunda küresel ekonomi alanında ciddi sıkıntılar yaşaması ihtimalini ortaya çıkarmaktadır. Ayrıca Endüstri 4.0 uygulamalarını etkin bir şekilde uygulayan ülkelerin, küresel ekonomi alanında önemli rekabet avantajları elde ettiği ve bu avantajların yaşanan gelişmeler ile daha da artacağı görülmektedir. Batılı gelişmiş ülkelere göre görece olarak daha düşük işgücüne sahip olan ve Dünyảnın ilk on büyük ekonomisine girmeyi hedefleyen Türkiye’nin de bu hedefini gerçekleştirebilmesi için Dördüncü Sanayi Devrimi çağına ayak uydurması bir zorunluluk haline geldiği görülmektedir. Bu nedenle, bu çalışmada Endüstri 4.0 çağı ve bu çağın küresel ekonomi ile Türkiye’ye olan etkileri incelenmiştir.

Anahtar Kelimeler: Dördüncü Sanayi Devrimi, Endüstri 4.0, Uluslararası Politik Ekonomi, Türkiye

\footnotetext{
* Prof. Dr., Marmara Üniversitesi, İşletme Bölümü, mozkan@marmara.edu.tr

** Dr. Öğr. Üyesi, Marmara Üniversitesi, Uluslararası İlişkiler Bölümü, arzu.al@marmara.edu.tr

*** Yükseklisans öğrencisi, Marmara Üniversitesi, İktisat Fakültesi, Uluslararası İktisat Anabilim Dalı, syavuz@marun.edu.tr
} 


\begin{abstract}
First Industrial Revolution, which is a product of steam engines invention in $18^{\text {th }}$ century, along with the spontaneous increase of scientific studies has caused increases in technological developments. This condition, after passing different stages till reaching 2000's, has paved the way for the Fourth Industrial Revolution. The main difference between the so-called Industry 4.0 and the other revolutions is the quick expansion of technological developments. Moreover, Fourth Industrial Revolution, which is also called Industry 4.0, causes serious paradigm changes in governments, businesses and even in all segments of the society. Production occurs with the interaction of different technologies and automation of the system in the production improves each day. This automation has been made possible through "cyber - physical systems", "internet of things", and "internet of services" terms, thus causing a continuous decline in the demand for human labor in the production process. Continuous decline in the demand for human labor along with wide-spreading automation, has emerged as a subject matter that needs to be evaluated in the framework of international political economy because eastern countries that attract foreign direct investments through their cheap labor will probably bring subtle problems in the global economy if these investments are withdrawn. Furthermore, countries that have effectively implemented industry 4.0 implementations are likely to gain significant competitive advantages in the global economy, and these advantages will be further enhanced by improved developments. Turkey, having less labor force as compared to the western countries and aiming to enter G10 countries, needs desperately to keep up with the Fourth Industrial Revolution era in order to reach this goal. Thus, this study through explaining the Industry 4.0 period evaluates its impact on global economy and Turkey.
\end{abstract}

Keywords: Fourth Industrial Revolution, Industry 4.0, International Political Economy, Turkey

\title{
Giriş
}

Son günlerde çok hızlı bir biçimde gelişerek hem kişisel yaşamımızı hem de toplumsal yaşamımızı derinden etkileyen değişim rüzgârları kendisini, özellikle bilişim ve iletişim alanlarında göstermekte ve ekonomiyi küresel düzeyde yönlendirdiği gibi ulusal ve uluslararası tüm işletmelerin bu değişimlerde pay sahibi olmasına olanak yaratmaktadır. Buradan hareketle bu çalışma da seçilen konu başlıkları ve içerikleri uluslararası ilişkiler ve işletme disiplinlerini kapsayacak şekilde oluşturulmuştur. Nitekim bu çalışmada kuramsal teorilerden daha çok teknik konular üzerinde özellikle durulmuştur. Değişimin öncüsü, Endüstri-Sanayi 4.0 olarak tanımlanan ve günümüzden yaklaşık 260 yıl kadar önce başlayan ilk Endüstri-Sanayi Devriminin 4. aşamasıdır. Endüstri-Sanayi 4.0 insan ile makinenin birleştirilmesi çalışmaları üzerine kurulmuş olup, insanın beyin gücü ile makinenin iş gücünü birlikte yapabilecek bir diğer ifadeyle insan-makine (endüstriyel robot) iş birliğini gerçekleştirecek yeni bir üretim aracının üretim faaliyetlerinde kullanılarak maliyet azaltımı ve verimlilik artışını hedeflemektedir. Ancak günümüzde insan robot iş birliğinde açıklığa kavuşturulacak pek çok hassas sorun vardır ve gelecekte de yeni sorunlar olacaktır. Örneğin robotlar için güvenlik zorunluluğu, çalışanların işlerini kaybetmeleri ve işsiz kalmaları gibi.

Geçtiğimiz günlerde Imec; Brüksel'deki Audide sonuçlarını sunduğu “Claxon” projesinde Claxon'dan insan operatörlerinin son nesil endüstriyel robotlarla ortak çalışma ortamında, 
olağan güvenlik merkezleri olmadan nasıl işbirliği yapabileceklerini araştırmaları istenmiş olup; proje iki odak noktası üzerinde yoğunlaşmaktadır.

Projenin ilk odak noktasını robotların insan çalışanlarıyla işbirliği yapmak için doğruluğundan ödün vermeden karşılaması gereken emniyet gereksinimleri gibi bir takım teknik konulara dikkat çekilmesi oluşturmaktadır. Ancak bu projeyi gerçekten benzersiz yapan şey, endüstriyel robotların insan tarafını ön plana çıkartan taraftır ve "İnsanlar robotlar tarafından ne kadar desteklenmek istiyor? ile "Bu yaklaşımı takip etmenin en iyi yolu nedir?" sorularının yanıtlarında gizlenmiştir.

Living Lab, Shirley Elprama ve Charlotte Jewell'den ve son aylarda Audi Brussels'deki personelle yapılan görüşmelerde Jacobs'un endüstriyel robotların geleceğine ilişkin vizyonunun tanıtılmakta olduğu; bu geleceğin, robotların öncelikle insan benzerlerinin yerine geçmek için, desteklenmesi üzerine kurgulanan-tasarlanan bir gelecek olduğu ve ayrıca gelecekteki çalışma arkadaşlarımız arasında insan robotlar olma ihtimalinin de gündeme geldiği ifade edilmektedir. Bilindiği gibi robotlar 1970’lerden beri üretimde özellikle ağır sanayinin tüm sektörlerinde kullanılmakta olup, otomobil üretiminde yüksek performanslı robot kollarının görüntüsü hepimizce bilinmektedir. Bunlar soldan sağa dönerek, en ağır bileşenleri-yükleri bile kolayca-çaba harcamadan kaldırıp hareket ettirebilmektedirler. Sahip oldukları bu güç nedeniyle, insanın yapamadığı pek çok iş tehlikesizce çok daha az maliyetle yapabilmektedir. İşte Endüstri-Sanayi 4.0 ile; endüstriyel robotlar ve insan emeği birbirlerine daha yakın etkileşime girdiğinde fabrikalarımız nasıl görünürdü? sorusuna kapsamlı bir çözüm aranmakta olup; insan çalışanlarının esneklik ve problem çözme yeteneklerinin, robotların güç ve hassasiyetiyle birleştirildiği bir senaryo olacaktır (Gilhuber, 2017).

Endüstri 4.0 kavramı aynı zamanda, endüstrideki üretim sürecinin dijital dünya ile bütünleştirilebilmesi ve sonucunda akıllı bir ürün geliştirme, verimliliği arttırılmış üretim, yüksek ve sürekli müşteriler ile lojistik ağından oluşan çok boyutlu bir sistemin ifadesidir. Artık, Endüstri-Sanayi 4.0 çok boyutlu bir sistem olarak günlük yaşamımızda yerini almakla birlikte, yazına Endüstri 4.0 olarak giren 4. Sanayi Devrimi kavramı yazında hem sanayi hem endüstri kavramının karşılığı olarak kullanılmaktadır. Gerçekte ise; sanayi ve endüstri kavramları farklı anlamlara haiz olup; üretimle yakından ilgilidir. ${ }^{4}$ Nitekim birçok disiplinden etkilenen, özellikle de ülkelerin ekonomik ve politik ilişkilerinde etkiye sahip olan bu devrimin çıtıları her geçen gün gelişmeye devam etmektedir. Yukarıda verilen bilgiler kapsamında çok boyutlu bir yapıya sahip olduğu görülen Endüstri-Sanayi 4.0 aşağıda şematik olarak verilmiştir (Gartner, 2015).

4 Üretim; insan gereksinimlerinin karşılanması amacıyla fayda yaratılması faaliyetleridir. Bir diğer ifade ile, yaratılan faydanın hammaddeden mamul üretimi olarak gerçekleştirilmesi SANAYİ, yaratılan faydanın hammadde kullanılmaksızın hizmet üretimi olarak gerçekleştirilmesi durumunda ENDÜSTRİ söz konusudur. Sonuçta, her iki üretim faaliyetinde de ekonomik değer yaratılarak mamul-ürün ve hizmet olarak ifade edilmektedir. Örneğin, sigortacılık endüstrisinden söz edilirken sigortacılık sanayi kavramı kullanılamadığı gibi, ağır sanayi faaliyetleri için ağır endüstri kavramını kullanmak hatalıdır. Bu nedenlerle bu çalışmada Endüstri-Sanayi 4.0 olarak kullanılması tercih edilmiştir 


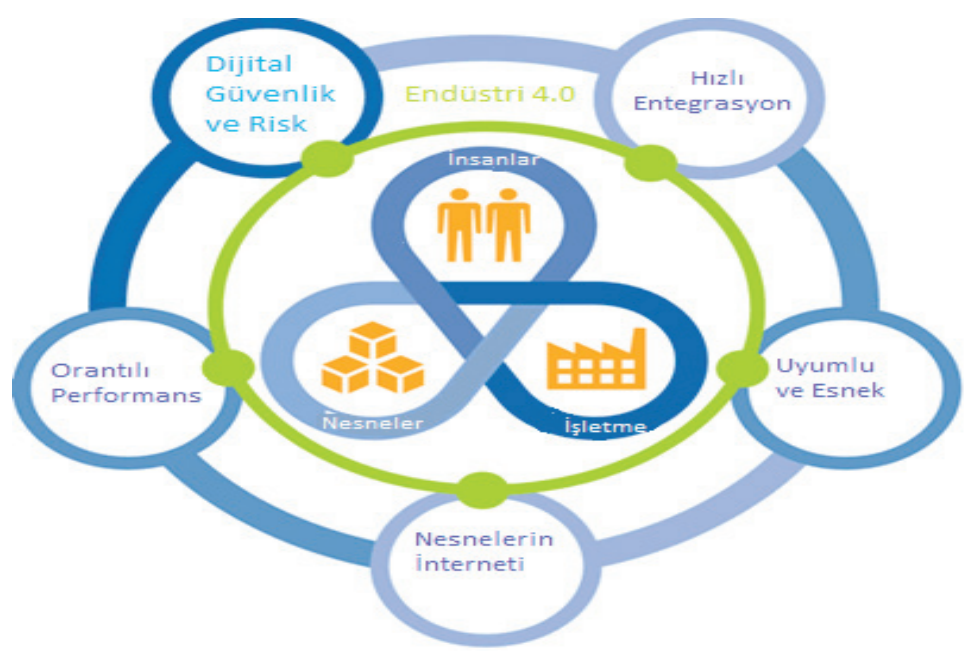

Şekil I. Çok Boyutlu Bir Sistem-Endüstri 4.0

\section{Dördüncü Sanayi-Endüstri Devrimi’nin Tarihsel Gelişimi}

M.Ö 10.000 yılına kadar, insanlar avcılık yapıp avladıkları hayvanları tüketerek hayatlarını sürdürmüşler, daha sonra avcllık-toplayıclık dönemini yaşamışlar ve bu dönemden sonra ise, yaşam şekillerini hayvan yetiştirmek, mahsul ekip biçmek, yoluyla değiştirerek yerleşik hayata geçmişlerdir. Bu durum, insanlık tarihinin ilk ve en önemli devrimlerinden biri olan tarım devriminin başlamasına neden olmuştur. Bu gelişme ile beraber sadece tüketen toplumlar aynı zamanda üreten toplumlar haline dönüşmüştür.

Yerleşik hayata geçen toplumlar üretimlerini daha verimli hale getirebilmek için, çeşitli yöntemler geliştirmeye ve M.Ö. 3.000-2.000 yılları arasında özellikle Mezopotamya bölgesinde insanlar çevrelerini inceleyerek matematiksel hesaplar yapmaya başlamıştır. M.Ö. 1000 yllına gelindiğinde ise, felsefe biliminin Yunan medeniyetinde ortaya çıkması ve yayılması birçok yeni anlayış ve düşüncenin gelişmesini tetiklemiş olup, özellikle astronomi ve doğa olaylarına olan ilginin artmasıyla keşif, buluş ve icatları ön plana çıkartmıştır.

M.S. 7.yy.dan itibaren İslamiyet' in doğuşu ve yayılması ile birlikte, Endülüs Emevileri döneminde bilim, kültür ve sanat alanında, sosyal ve ekonomik yaşamda gerçekleştirilen tüm çaba ve gayretler gelişim ve değişimleri hızlandırarak yepyeni bir dönemin başlangıcı olmuştur. Yapılan bilimsel çalışmalar bilim ve tekniğin ilerlemesinde büyük öneme haiz roller üstlenmiştir.

11. yy'da Çinliler tarafından manyetik pusulanın ve barutun bulunmasıyla, ateşli silahların icat edilmesi ve bunların hızlandırdığı çalışmalar sonucunda bugünkü bilim ve teknolojinin temelleri atılmış olup; 15. yy'da İtalya'da ortaya çıkan Rönesans ve Reform hareketleri, bu dönemin bilim tarihinin en önemli dönüm noktalarından biri olmasına neden olmuştur(Ural, 1998, s.211). 
Matbaanın icadı ve yayılması ile birlikte de okuryazarlık oranı artmış, bilimsel çalışmalar kendisini her sahada göstererek eski dönemlere göre, dünyayı tümüyle farklılaştırmış, tabulaşan ideoloji, fikir ve düşünceler yıkılmıştır. Bir diğer ifadeyle bilimsel yaşam tüm dünyayı aydınlatarak köklü değişimler yaratmıştır.

18. yy’ın ikinci yarısında bu gelişim ve değişimler tarım ve sanayi devrimleri ile önemini arttırarak korumuştur (Schwab, 2017, s.15). Sanayi Devrimi, başta İngiltere olmak üzere batı toplumlarında köklü değişikliklere yol açmışır, ancak bu değişikliler aniden ortaya çıkmamıştır ve hala günümüzde de etkilerini sürdürmektedir (Tanilli, 2004, s.118). İnsanlık tarihine bakıldığında tarım devriminden sanayi devrimine geçişte oldukça uzun bir sürecin yaşandığı görülmektedir. Fakat 18. yy’n ortalarından sonra buharlı makinelerin icadıyla başlayan birinci sanayi devrimi ile yaşanan gelişmeler çok daha hızlı olmuş olup; hala sürmektedir.

Birinci sanayi devrimi ilk olarak 1712 yllında Thomas Newcomen’in icat ettiği bir buhar makinesi ile ortaya çıkmış ve 1760 'lı yıllarda geliştirilen buhar makinesi aynı yüzyılın sonlarında dokuma tezgâhlarında kullanılmaya başlanmıştır. Bu büyük devrim demiryollarının inşası ve buhar makinelerinin katkısıyla mekanik üretime imkân sağlamıştır (Schwab, 2017, s.16). Hem küçük atölyelerin yerini fabrikaların alması hem de üretimin makinelerin kullanılmasıyla daha kolay ve seri hale gelmesi, özellikle birinci sanayi devriminin ortaya çıtığı ülke olan İngiltere’de etkili biçimde kullanmıştır.

İkinci sanayi devrimi, 19. yüzyılın sonlarında üretimde elektriğin kullanılması ve elektrik gücünün montaj hatlarını yönlendirmesi ile ortaya çıkmıştır. İkinci sanayi devriminin başlamasında Ford Motor fabrikalarında kurulan elektrik sistemleri daha etkili olmuştur. Bu sistemler sayesinde seri üretime geçilmiş ve buda üretim hacminin artmasıyla birlikte maliyetlerin ve fiyatların düşmesine neden olmuştur (Eğilmez, 2017). Fordizm-Ford Dönemi olarak adlandırılan bu dönemde üretimin esnek ve yüksek verimlilik ile organizasyonun sağlanması sonucu daha ucuz otomobil üretilmesi amaçlanmıştır. H. Ford'un "Oto siyahsa, müşteri arabasını istediği renge boyayabilir." sözüyle ifadesini bulan bu anlayış batının bugünkü ekonomik üstünlüğünün temellerini oluşturmaktadır (Weckbordt, 2015).

İkinci sanayi devrimi; elektriğin, bilim bazlı kimyasalların, telgrafın yayılması ve telefonun keşfedilmesiyle iletişim teknolojilerinin yayılmasına da neden olmuştur. Bu sanayi devriminde, ilk örneğinden farklı olarak bilimsel bilginin önemi ortaya çımıştır (Castells, 2013, s.43). Bilimsel bilgi tabanlı iletişim teknolojilerinin yayılması bir sonraki sanayi devrimi olan üçüncü sanayi devriminin ortaya çıkmasını da tetiklemiştir.

Bilimsel bilginin daha aktif olarak kullanılmasıyla birlikte 1968 yllında geliştirilen programlanabilir makineler, üçüncü sanayi devriminin başlamasına neden olmuştur. Bu dönemin başlaması ile birlikte Fordizm üretimden Post-Fordizm üretime geçilmiştir. (Alçın, 2016, s.21). Nitekim bilgisayarların kullanılmasıyla birlikte üretim daha kolay hale gelmiş ve insan emeğine olan gereksinim azalmıştır. Ayrıca internetin yaygınlaşması ve ulaşım imkânlarının artması da üretimi 
ciddi anlamda olumlu yönde etkilemiştir. Bütün bu gelişmeler sayesinde dünya daha entegre hale gelmeye başlamış ve üretim küreselleşmiştir. Üç sanayi devrimi, birlikte değerlendirildiğinde;

-Devrimler arası sürelerin kısalması,

-Ortaya çıkan her yeni sanayi devriminde bir öncekine oranla özellikle üretim sektöründe emeğe olan ihtiyacın azalması, (Eğilmez, 2017)

olmak üzere karışımıza iki önemli özellik çıkmaktadır. Buna bağlı olarak da insan emeğinin sermaye ile ikame edilebilmesi; sermayenin gücünü ve önemini arttırmıştır. Bir diğer ifade ile Emek Yoğun Teknoloji yerini Sermaye Yoğun Teknolojiye bırakarak sanayi devrimlerini ortaya çıkarmıştır.

Emek Yoğun Teknoloji (Labor-intensive Technology); bir malın üretiminde veya bir kesimde kullanılan emek/sermaye oranının diğer bir malın üretiminde veya diğer bir kesimde kullanılandan daha yüksek olduğu teknolojidir. Sermaye Yoğun Teknoloji; (Capital-intensive Technology) ise; bir malın üretiminde veya bir kesimde kullanılan sermaye/emek oranının, diğer bir malın üretiminde veya diğer bir kesimde kullanılandan daha yüksek olduğu teknoloji olarak tanımlanmaktadır. Ancak süregelen “Emek Yoğun Teknoloji mi? Sermaye Yoğun Teknoloji mi?” tartışmalarının bugün emek ve teknolojinin birleştirilerek son bulması bugün Endüstri 4.0 ile gerçekleştirilmiştir.

Endüstri 4.0’ın ekonomiye getirdiği en büyük yenilik; teknolojide olmayan ve insanda olan beyin ile, teknolojide olan insanda olmayan yüksek verim/randımanın yazılım yolu ile ortadan kaldırılmasıdır. Bunun sonucu ekonomiye üretim artışı olarak yansımış ve yeni iş sahaları ortaya çıkmıştır. Ancak, genellikle fabrika çalışanları ve kişiler arası iletişimin üretimde yaşanan değişimin gölgesinde kalarak karmaşıklığın daha da artacağı ifade dilmektedir (Blum, 2016).

Bütün bu gelişmeler ilk kez 2011 Hannover fuarında gündeme gelen "Endüstri 4.0" yani dördüncü sanayi devriminin ortaya çıkmasına neden olmuştur. 2000’li yıllarda ortaya çıkan bu devrim, dijitalleşme temelleri üzerinde yoğunlaşmaktadır. Dijitalleşme her ne kadar üretim sürecinde tam olarak kullanılmasa da mobil ağların ve internetin hızla yaygınlaşması, yapay zekâ ile makinelerin kullanılması ve bunların çok daha fazla gelişip bütünleşmesi dördüncü sanayi devriminin başlamasına neden olmuştur (Schwab, 2017, s.16). Daha açık bir ifade ile yaşanan bu son sanayi devrimi üretimde bilgisayarların kullanılmasını ciddi anlamda yaygınlaştırmış olup, yüksek teknoloji kullanımını ön plana çıkarmıştır (Eğilmez, 2017).

Dördüncü sanayi devrimi, diğer sanayi devrimlerine göre çok daha hızlı gelişmektedir. Ayrıca, çeşitli teknolojileri bir araya getirerek ekonomide ve toplumda ciddi anlamda paradigma değişiklerine neden olmaktadır. Bu da ülkeler, şirketler ve sektörler olmak üzere tüm toplumu bütünsel bir biçimde dönüştürmektedir (Schwab,2017, s.11).

$\mathrm{Bu}$ dönüşüm, gelecekte insanlığın nasıl bir dünya ile karşılaşacağı konusunda ciddi soruları beraberinde getirmektedir. Özellikle bu değişim hızının ne boyutlarda olacağı ve kurumların bu 
hıza ne ölçüde karşılık vereceği önemli bir soru olarak ortaya çıkmaktadır. Ayrıca, Dördüncü Sanayi Devrimi ile ortaya çıkabilecek yeni iş sahalarında emek ihtiyacının ne oranda olacağ 1 önemli bir tartı̧ma konusu olmakta ve pek çok sorunun beraberinde getirmektedir. Bu sorulara bağlı olarak varılabilecek yargı; bu dönüşümden bütün toplumların ekonomik, sosyal, kültürel ve siyasi olarak etkilendiği hatta etkilenmeye devam edeceğidir.

Bir diğer ifadeyle, Endüstri 4.0’’n gerçekte ne olduğu hususunda halen "İster bir devrim ister evrimsel bir süreç ya da belki de sadece robot üreticilerinin ekonomi-politikacılarının sabit bir pazarlama düşüncesi olduğu" vb. birçok farklı görüş bulunmaktadır (Weckbrodt, 2015).

Endüstri 4.0 olarak da adlandırılan Dördüncü Sanayi Devrimi, akıllı fabrikaları ortaya çıkararak sanal ve fiziksel üretim sistemlerinin etkileşimini sağlamaktadır. Böylece ürünler daha kolay bir şekilde müşteriye özel hale getirilebilmekte (Schwab, 2017, s.17) ve bu durum aynı zamanda tüketici faydasında artış yaratmaktadır. Bu devrim, ürünleri daha kaliteli hale getirmekte ve üretkenliğin artırmasına neden olarak müşterilerin talep ve isteklerini de değiştirmektedir. Ayrıca, şirketlerin iş birliği içerisine girmelerinin önemi anlaşılması da yeni ortaklıkların ortaya çıkmasını da tetiklemektedir (Schwab, 2017, s. 62)

Endüstri 4.0 ya da 4. Sanayi Devrimi, birçok çağdaş otomasyon sistemini, veri alışverişlerini ve üretim teknolojilerini içeren kolektif bir terimdir. Bu devrim nesnelerin interneti, internetin hizmetleri ve siber-fiziksel sistemlerden oluşan bir değerler bütünüdür. Aynı zamanda bu yapı, akıllı fabrika sisteminin oluşmasında büyük rol oynar. Bu devrim, üretim ortamında her bir verinin toplanmasına ve iyi bir şekilde izlenip analiz edilmesine olanak sağlayacağı için daha verimli iş modelleri ortaya çıkacaktır. Buradan hareketle;

- Illk sanayi devrimi (1.0) su ve buhar gücünü kullanarak mekanik üretim sistemlerini geliştirmiştir.

- İkinci sanayi devrimi (2.0) ile elektrik gücünün yardımıyla seri üretime geçilmiştir.

- Üçüncü sanayi devrimiyle (3.0) ise dijital devrim, elektroniklerin kullanımı ve BT (Bilgi Teknolojileri)'nin gelişmesiyle üretim daha da otomatikleşmiştir (Bauernhansl and Hompel, 2014, s. 5-7).

Buna bağlı olarak ta günümüzde ön plana çıkan Dördüncü Sanayi Devrimi’nin bu gelişimi tarihsel akışı içinde aşağıda tabloda özetle gösterilmiştir (Rayeling, 2017). 
Tablo I. Endüstri 4.0’’n Tarihsel Gelişimi

\begin{tabular}{|l|}
\hline Mekanik Üretim Tesislerinin Uygulanması (18. Yüzyıl) \\
•1712 Buhar Makinesinin İcadı \\
\hline Elektrik ve İş Bölümüne Dayalı Seri Üretime Geçilmesi(19.-20. Yüzyl) \\
• 1840 Telgraf ve 1880 Telefon İcatları \\
•1920 Taylorizm (Bilimsel yönetim) \\
\hline Üretim Süreçlerinin Otomasyonu (20. Yüzyll) \\
• 1971 İlk mikro bilgisayar (Altair 8800) \\
•1976 Apple I (S. Jobs ve S. Wozniak) \\
\hline Otonom Makineler ve Sanal Ortamlar (21. Yüzyll) \\
-1988 AutoIDLab. (MIT) \\
-2000 Nesnelerin İnterneti \\
-2010 Hücresel Taşıma Sistemi \\
2020 Otonom Etkileşim ve Sanallaştırma
\end{tabular}

\section{Sanayi-Endüstri 4.0 Devrimi’nin Kavramsal Çerçevesi}

Teknolojik gelişmeler sayesinde artan üretim verimliliği, doğu ve batı ülkelerinin rekabete dayalı ekonomik ilişkileri, esnek üretimin yaygınlaşması ve ürünün piyasaya daha hızlı girmesi gibi nedenler, Endüstri 4.0’’n ortaya çıkmasının en önemli nedenleridir (Yazıcı ve Düzkaya, 2016, s. 64). Özellikle gelişmiş ülkelerdeki emek maliyetlerinin gelişmekte olan ülkelere göre daha yüksek olması, bu sanayi devriminin oluşmasına ve hatta teknolojik gelişmelere paralel olarak hızlanmasına neden olmuştur. Fordist üretim sistemi olarak adlandırılan seri üretim sistemlerinin de müşteri beklentilerini tam olarak karşılayamaması, Dördüncü sanayi devrimine geçişte en önemli etkenlerden birisidir.

Öte yandan bireyselleşme (üretimde insan gücünün azaltılması ve insanın kendine daha çok zaman ayırması anlayışı) ve hızla değişen talep eğilimi, şirketleri üretim ve iş modellerini daha esnek hale getirmeye zorlamakta ve buna bağlı olarak da dijital teknolojilerin sürekli kullanımı ile dördüncü sanayi devrimine tüm ön koşulları sunulmaktadır. Gerçekten de Sanayi-Endüstri 4.0, imalat sektörünü yeni bir optimizasyon alanına sokmak için yeni teknolojilerin ve emeğin örgütlenmesinin kombinasyonu olup, makine ve insanlar arasındaki yenilikçi iletişim ve tasarım sayesinde akıllı fabrikalar yaratmaya odaklanan bir eğilimdir (The European Files, 2017).

Ancak üretimde kullanılan teknolojilerin yoğunlaşması bir diğer ifade ile teknoloji yoğun üretim türünün ön plana çıkması ve neredeyse yalnız kalmış olması bu durumun sadece bir yönüdür. Çünkü işletmenin tüm alanlarında aniden-hiç beklenmeyen tümüyle yeni olan ve yanıtlanması beklenen sorular ortaya çıkmaktadır. Bu durumda, yeni stratejilerin oluşturulmasında kullanılan iş modellerinin yenilenmesinden başlayarak, tüm prosedürlerin değiştirilmesinin yanı sıra, sermaye yapısını etkileyen tüm faaliyet ve girişimlerin irdelenerek ve nasıl uygulandığg göz önüne alınmak zorundadır (Klemp and Pattebaum, 2016, s.1-2). 


\section{Sanayi-Endüstri 4.0'ın Yapısı ve İlkeleri}

Endüstri 4.0, teknolojilerin ve değer zinciri organizasyonları kavramlarının kolektif bir bütünü olarak karşımıza çıkmakta ve genel olarak siber fiziksel sistemlerin yapısı, nesnelerin interneti ve hizmetlerin interneti olmak üzere üç temel yapıdan oluşmaktadır. Sonraki bölümlerde daha detaylı bir biçimde incelenecek olan bu kavramları kısaca şöyle açıklayabiliriz.

Nesnelerin İnterneti; herhangi bir nesneden üretilen verilerin, bir ağ aracılığıyla başka sistemlere aktarılmasıdır. Yani bir cihaz, akıllı okuyucu ya da insandan üretilen verilerin başka sistemlere aktarılması durumuna Nesnelerin İnterneti denilmektedir (Rouse, 2016). Fiziksel cihazlar, makineler, taşıtlar ve çeşitli elektronik donanım içeren nesnelerin veri iletişimini sağlamak için kurmuş oldukları ağ sistemleri, Nesnelerin İnternetini oluşturmaktadır (Banger, 2017, s. 43).

Siber Fiziksel Sistemler; enformasyon teknolojisinden yararlanarak iletişimi, fiziksel süreçleri ve bilişsel mekanizmaları yöneten ve izleyen sistemlerdir. Endüstri 4.0’’n en önemli kavramlarından biri olan Siber Fiziksel Sistemler medikal izleme, otonom taşıt hizmetleri ve robotik cihaz gibi birçok alanda kullanılmaktadır (Banger, 2017, s. 46).

Hizmetlerin interneti ise; hizmet satıcılarına internet yoluyla hizmetlerini sunma imkânı veren sistemlerdir (Herman and Pentek, Otto, 2015, p.9). Hizmetlerin interneti, hizmetlerin sunulabilmesi için iş modellerinden ve hizmet altyapılarından oluşmaktadır.

Yukarıda yapılan açıklamalar doğrultusunda Endüstri 4.0’’n yapısı aşağıdaki şema üzerinde gösterilmiştir (Selek, 2017)

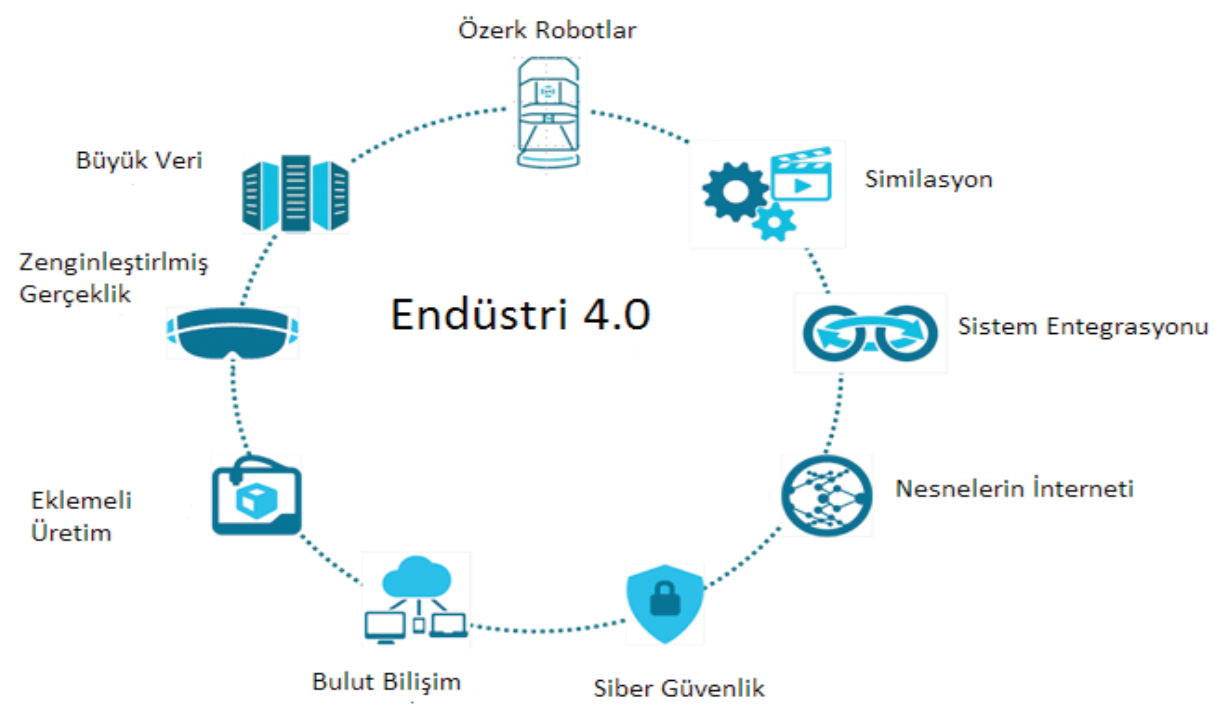

Şekil 2. Endüstri 4.0’’n Yapısı 
Endüstri 4.0 ile modüler yapılı akıllı fabrikalar kapsamında, fiziksel işlemleri siber-fiziksel sistemlerle izlemek, fiziksel dünyanın sanal bir kopyasını oluşturmak ve merkezi olmayan kararların verilmesi hedeflenmektedir. Nesnelerin interneti ile siber-fiziksel sistemler birbirleriyle ve insanlarla gerçek zamanlı olarak iletişime geçip iş birliği içinde çalışabilecektir. Hizmetlerin interneti ile hem iç hem de çapraz örgütsel hizmetler sunulacak ve değer zincirinin kullanıcıları tarafından değerlendirilecektir.

Endüstri 4.0, temel olarak 6 ilke üzerine kurulmuş olup, bu ilkeler şunlardır (Herman and Pentek, Otto, 2015, p.11):

- Karşılıklı Çalışabilirlik: Siber fiziksel sistemlerin yeteneği ile (örn. iş parçası taşıyıcıları, montaj istasyonları ve ürünleri) nesnelerin interneti ve hizmetlerin interneti üzerinden insanların ve akıllı fabrikaların birbirleriyle iletişim kurmasını içerir.

- Sanallaştırma: Bu yapı akıllı fabrikaların sanal bir kopyasıdır. Sistem, sensör verilerinin sanal tesis ve simülasyon modelleri ile bağlanmasıyla oluşur.

- Özerk Yönetim: Siber-Fiziksel sistemlerin akıllı fabrikalar içinde kendi kararlarını kendi verme yeteneğidir.

- Gerçek-Zamanlı Yeteneği: Verileri toplama ve analiz etme yeteneğidir. Bu yapı anlayışın hızlıca yapılmasını sağlar.

- Hizmet Oryantasyonu: Hizmetlerin interneti üzerinden siber-fiziksel sistemler, insanlar ve akıllı fabrika servisleri sunulmaktadır.

- Modülerlik: Bireysel modüllerin değişen gereklilikleri için akıllı fabrikalara esnek adaptasyon sistemi sağlar.

\section{Endüstri 4.0 Sistemin Uygulanabilirliği ve Avantajları}

Endüstri 4.0 sistemindeki üretim, makinelerin hizmet sundukları ve ürünlerle gerçek zamanlı olarak bilgi paylaştıkları bir sisteme benzetilmektedir. Alman Yapay Zeka Araştırma Merkezi (DFKI), içinde Siemens’in de bulunduğu 20 endüstriyel ve araştırma ortağının katkısıyla kurulan Almanya, Kaiserslautern'deki küçük bir akıllı fabrikada bu gibi bir sistemin uygulamada nasıl çalışacağını sergilemektedir. Ürünler ile imalat makinelerinin birbirleriyle nasıl haberleşebileceklerini göstermek için sabun şişelerinden faydalanılmaktadır. Boş sabun şişelerinin üzerinde radyo frekansıyla tanımlama (RFID) etiketleri vardır ve bu etiketler aracılığı ile makinelerin şişelerin rengini tanıması sağlanmaktadır. Bu sistem sayesinde bir ürünün radyo sinyalleriyle ilettiği bilgiler, üretimin başından itibaren dijital ortamda saklanmasına olanak sağlanmaktadır. Bu şekilde bir siber fiziksel sistem ortaya çıkmaktadır ki açıklanan bu durum şematik olarak şöyledir: 


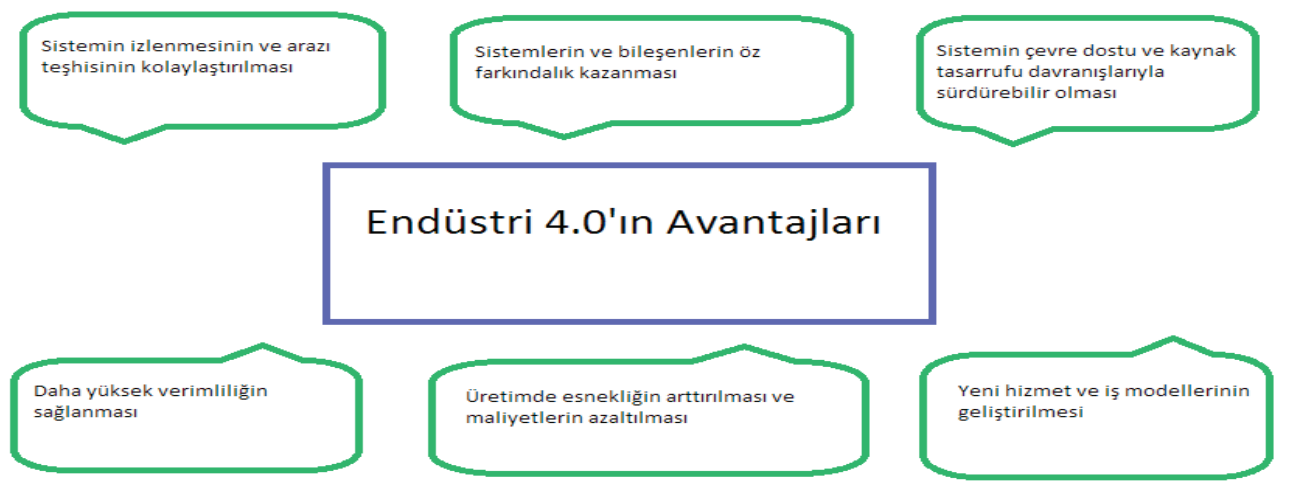

Şekil 2. Endüstri 4.0’ın sistematik şeması

Şekilden de görülebileceği gibi, Endüstri 4.0 üretimde büyük yenilikler, kolaylıklar ile birlikte verimlilik artışı ile maliyet tasarrufu sağlamakta olup kullanıcılarına ve işletme organizasyonlarına çok önemli avantajlar-yararlar sağlamakta olup; bu avantajlar-yararlar şunlardır (Blum,2016, Schulze, 2014):

a) Kullanıcılara sağlanan avantajlar-yararlar;

- Tedarik zincirinin şeffaflaşması,

- Siparişlerin (işlemlerinin) basitleştirilmesi,

- Bilgi kanallarının sadeleştirilmesi,

- Tedarik edilen makine teçhizatın kontrolünün hızlanması,

- Stokların optimizasyonun kolaylaştırılması,

- Teslimatta güvenin yükseltilmesi,

- İnsan ve makine işbirliğinin sağlanması,

- Üretimde esnekliğin ve yüksek verimliliğin sağlanması.

b) İşletme organizasyonuna sağlanan avantajlar-yararlar;

- Personel seçimi ve eğitiminin kolaylaşması,

- İşletme organizasyonunda yetki ve sorumlulukların daha kolay belirlenmesi,

- OÖrgütsel iletişimin yükseltilmesi, bilgi dağılımının eş zamanlı ve kolayca yapılması,

- $\quad$ İsücü ve verimliliğin yükseltilmesi. 


\section{Endüstri 4.0 Sistemi}

Endüstri 4.0 bir sistem olarak bugün günlük yaşamımızda yerini almış olup, bu sistemi oluşturan alt sistemler bu bölümde ayrıntılı olarak açıklanacaktır.

\section{Siber-Fiziksel Sistemler, Özerk Taşıtlar, 3D Yazıcılar Ve Akıllı-Karanlık Fabrikalar}

Endüstri 4.0’’n çok boyutlu olmasının ve teknolojik gelişmelerin hızlı olmasının temelinde yatan unsurlar siber fiziksel sitemler olarak karşımıza çıkmaktadır. Bu sistemin sağlamış olduğu imkânlardan bazıları şunlardır:

- Özerk taşıtların ortaya çıkması ve hızlı bir şekilde yayılması,

- İleri robot teknolojisinin gelişmesi,

- Akıllı fabrikaların ortaya çıkması,

- 3D yazıcıların gelişimi,

Siber fiziksel sistemler, fiziksel dünya ile siber alanı internet aracılığıla birbirine bağlayan sistemlerdir (Rudtsch and Gausemeier, Gesing, Mittag, Peter, 2014, p. 314). Bu sistemler fiziksel gerçeklik ile siber ilişkisini kurabilmek için sensörleri, aktüatörleri, bilgisayar ve yazılım sistemlerini, iletişim teknolojilerini kullanmaktadır( Ghafory, 2017). Sonuç olarak, bu sistemler sayesinde sanal dünya ile gerçek dünya arasında etkileşim sağlanmakta ve üretim çok daha kolay hale gelmektedir.

Siber fiziksel sistemler, akıllı fabrikaları (siber fiziksel üretim sistemini) ortaya çıkarmaktadır. $\mathrm{Bu}$ sistem, üretimde sadece otomasyon teknolojisini geliştirmemekte, aynı zamanda karar alma süreçlerini ve gözlem kabiliyetini de geliştirmektedir. Bu sistemle birlikte üretim süreci, merkezi bir kontrol sistem yerine sensör sistemleri sayesinde otomatik bir şekilde gerçekleşmektedir. Dolayısıyla bu üretim sistemi kendi kendini kontrol edebilir hale gelmekte, süreçleri gözleyebilmekte ve herhangi bir arızanın ortaya çıkması durumunda karşı önlemleri harekete geçirebilmektedir (Rudtsch and Gausemeier, Gesing, Mittag Peter, İbit, 2014, s.314). Daha açık bir ifadeyle, bu durum üretim sürecinde insan müdahalesinin azaldığını hatta ortadan kalktığını göstermektedir.

Akıllı fabrikaların ortaya çıkarak, ürünlerin çeşitlenmesi ve müşteri taleplerini daha hızlı bir biçimde karşılık verilmesini olanak sağlamış olması ekonomik büyümeyi destekleyici bir unsur olarak görülmektedir (Alçın, 2016, s. 26).

Önceden otomotiv gibi belli endüstrilerde yoğun bir kontrol sistemiyle kullanılan robotlar, günümüzde birçok endüstride alanında kullanılmakta ve bu kullanım giderek hem ulusal hem de uluslararası alanda yayılmaktadır. Ayrıca, diğer teknolojilerdeki ilerlemeler robot teknolojisinin gelişmesine yardımcı olmakta ve robotlar daha uyarlanabilir hale gelmektedir. Özellikle sensör teknolojisinin gelişimi ile robotların çevrelerini daha iyi algılaması ve bu doğrultuda tepki vermesi mümkün olmaktadır( Schwab, 2017, s. 25). Bu durum, robot teknolojisinin gelişmesi ile 
insan hayatında daha aktif rol alacağını göstermekte, hatta ileri robot teknolojisinin gelişmesi de akıllı fabrikaların gelişmesi anlamına gelmektedir.

Medyaya bakıldığında genellikle sürücüsüz arabalar ile elde edilen gelişmeler yer alsa da kamyonlar, dronlar, uçaklar gibi çok çeşitli özerk taşıtlar da karşımıza çıkmaktadır. Sensörlerin ve yapay zekâların kullanılması ile birlikte bu taşıtlar hızlı bir şekilde gelişmeye devam etmektedir (Schwab, 2017, s. 24). Nitekim mevcut trendler ilerleyen yıllarda sürücüsüz taşıtların daha geniş alanlarda kendine yer bulacağını göstermektedir.

3D baskısı denilen şey; dijital bir çizimden fiziksel bir nesne oluşturma işlemi olarak nitelendirilmektedir. Bu teknoloji günümüzde otomobil, havacılık ve medikal endüstrilerinde sınırlı bir kapasiteye sahip olsa da, maliyetlerin düşürülmesi ile çok farklı alanlarda da kullanılabilecektir. Hatta, insan hücre ve organlarının da bu kapsama dâhil olabileceği düşünülmektedir (Schwab, 2017, s. 24). Çok kısa sürede oluşturulan ev yapımı haberleri sosyal medyada karşımıza çıkmıştır. Şüphesiz, 3D yazıcıların gelişmesiyle birlikte üretimde kolaylığın sağlanmasının yanı sıra çeşitlilikte artacaktır. Bu da, tüketici isteklerinin daha iyi karşılanacağı anlamina gelmektedir.

\section{Nesnelerin İnterneti(IoT), Büyük Veri (Big Data) Teknolojisi}

Nesnelerin Interneti (Internet of Things-IoT) kavramı, ilk olarak Kevin Ashton'un 1999 yılında Procter \& Gamble isimli şirket için hazırladığı bir sunumda kullanılmıştır. Nesnelerin interneti; herhangi bir zaman ve mekânda nesnelerin başka bir deyişle cihazların birbirlerine bağlanabilmesi teknolojisi anlamına gelmektedir (Çavdar ve Öztürk, 2018). Bu kavram, akıllı cihazların internete bağlanması sayesinde verilerin kontrol edilmesi ve uygulama sürecinin yürütülmesi olarak da açıklanabilir (Keseayak, 2017).

IoT, sensörler ve bioçipler ile Wi-fi Zigbee, GPS, Bluetooth gibi teknolojileri kullanarak elde ettiği verileri bilgi haline getirip hem birbirleriyle hem de insanlarla iletişime geçen akıllı nesneleri ortaya çıkarmaktadır (Büyük ve Öz, 2017, s. 43). Bu iletişimin olumlu etkileri, birçok alanda özellikle insanların sosyal yaşamı için sağladığı kolaylıklarla karşımıza çıkmaktadır. Nesnelerin İnterneti; E-sağlık, Akıllı Çevre, Akıllı Şehirler, Lojistik gibi birçok konuda uygulama alanı bulmaktadır. Bu alanlarda daha kaliteli hizmet verebilmek için (Gökrem ve Bozuklu, 2016, s. 49);

- Sensörlerden gerekli veriler toplanması

- Bu veriler depolanması,

- Depolanan veriler, makine öğrenimi yöntemleri ile analiz edilmesi ve

- Gerekli iyileştirmelerin yapılmasına olanak sağlanması aşamalarının gerçeklemesi ile olasidir. 


\section{Sanayi-Endüstri 4.0 Devrimi'nin Etkileri}

Dördüncü sanayi devriminin dünya ekonomisi üzerinde çok yönlü etkileri olacağı ve bu durumun tüm makro değerleri etkileyeceği öngörülmektedir (Schwab, 2017, s.38). Bu etkinin verimliliği, istihdamı ve ekonomik büyümeyi ne ölçüde etkileyeceği merakla ve şüpheyle beklenmekte olup, şüpheleri ve olumsuzlukları ortadan kaldırmak için pek çok çalışma yapılmaktadır.

Özellikle, Almanya bu hususta en öndeki-lider ülke olarak; Industrie 4.0 Ulusal Platformunu oluşturarak Nisan 2013’te Hannover Messe'de kuruluşunu gerçekleştirdi. O günden itibaren, meteorik bir yükseliş yaşayan Endüstri 4.0 kavramı şimdilerde neredeyse enflasyon kavramı gibi çok sık kullanılmaktadır (Bauernhansl and Hompel, Heuser, 2014). AR-GE faaliyetleri göz önüne alındığında en başta olmak üzere Almanya ve diğer gelişmiş ülkeler, bu hususta ki çabalarını yoğunlaştırmakta ve hatta iş birliği anlaşmaları dahi yapmaktadır. Örnek olarak; Almanya ve Çin arasinda,

- $\quad 15$ Temmuz 2015 tarihli "Yenilikte Birlikte" iş birliği planı,

- 19 Ocak 2016 tarihli “Bilim ve Teknoloji” memorandumu,

- 18 Ekim 2016 tarihli BMWi-Çin iş birliği çerçevesi,

- 29-30 Kasım 2016 tarihli BMWi-Çin sempozyumu,

Almanya ve Japonya arasinda ise,

- 19 Mart 2017 tarihinde imzalanan "Hannover Beyannamesi” gösterilebilir. ${ }^{5}$

\section{Dünya Ekonomisi Üzerine Etkileri}

Endüstri 4.0’’n bugün ekonomik yaşamdaki yerini almasıly birlikte ekonomi üzerindeki etkileri de ortaya çıkmaya başlamıştır. Bu etkiler makro düzeyde ülke ekonomileri-milli ekonomiler, mikro düzeyde her sektörde faaliyette bulunan tüm gerçek ve tüzel kişi işletmeler üzerinde görülmektedir.

\section{Büyüme ve Verimlilik Üzerine Etkileri}

2008 Küresel Finansal Krizi’nden önce, dünya ekonomisi ortalama olarak \%5 oranında büyüme göstermiştir. Beklentiler, krizden sonra tekrar önceki büyüme oranlarına dönüleceği yönünde olsa da bu gerçekleşmeyerek, ortalama büyüme hızı \%3’lerde kalmıştır (Schwab, 2017, s.39). Teknolojik gelişmelerin önceki dönemlerden farklı olarak doğrusal değil de üstel bir şekilde ilerlemesine rağmen büyüme oranlarının neden beklenildiği şekilde artmadığ tartışma konusu olmuştur.

5 Joint Statement on Cooperation between the Federal Ministry for Economic Affairs and Energy of the Federal Republic of Germany and the Ministry of Economy, Trade and Industry of Japan regarding the Internet of Things/ Industrie 4.0, https://www.bmwi.de/Redaktion/DE/Downloads/J-L/joint-statement-on-cooperation-regarding-theinternet-of-things-industrie-4-0.pdf?_blob=publicationFile\&v=7, (E.T.:11.01.2018) 
Dünya Ekonomik Forumu kurucusu ve başkanı Klaus Schwab’n Dördüncü Sanayi devrimi adlı kitabında açıkladığı üzere bu devrim ile ilgili farklı görüşler bulunmaktadır. Bir görüşe göre; dördüncü sanayi devriminin katkılarının gerçekleştiği ve verimlilik üzerine olan etkisinin neredeyse ortadan kalktığı iddia edilirken, diğer bir görüşe göre; gelişen teknolojilerin, verimlilikte ve ekonomik büyümede yeniden büyük bir yükselişe neden olacağı ileri sürülmektedir (Schwab, 2017, s. 41).

19. yüzyıl ile İkinci Dünya Savaşı arasındaki yıllarda verimlilikte ortalama bir artış sağlanmıştır. Özellikle, sanayileşmenin geliştiği 1950 ile 1973 yılları arasında verimlilik artışı hızlanmıştır. Ancak 1973’ten 1990’a kadar geçen sürede teknolojik gelişmelerin büyüklüğüne rağmen verimlilik artış oranları yavaşlamıştır. Bu durum, teknolojik gelişmelerin hızlandığını ancak verimlilik artış hızının bu hıza karşılık veremediğini göstermektedir. Teknolojik gelişmelerin tüm ekonomide karşllık bulması için toplumda, şirketlerde ve üretim süreçlerinde bu gelişmeler doğrultusunda önemli değişikler olması gerekmektedir (Castells, 2013, s.108).

Özellikle, son 10 yıldır teknolojik gelişmelere rağmen verimlilik oranları yüksek seviyelere çıkamamıştır. Dördüncü sanayi devrimindeki ürünler daha işlevsel ve kaliteli olmasına rağmen geleneksel piyasalardan farklı piyasalarda satılmaktadır. Bu ürünlerin marjinal maliyeti yoktur ve rekabeti çok yüksektir. Dolayısıyla bu durum, fiyatların düşük seviyelerde olmasına neden olmaktadır. Bu da tüketicilerin elde ettiği faydanın, genel satışlara tam olarak yansımaması nedeniyle verimliliği düşük gösteriyor olabilir (Schwab, 2017, s. 40).

$\mathrm{Bu}$ durum, dördüncü sanayi devriminin verimlilik oranlarında ve dolayısıyla büyüme oranlarındaki ani sıçrama potansiyelini göstermektedir.

Bir diğer görüş ise, dördüncü sanayi devriminin henüz ilerleyen zamanlarda verimlilik üzerine büyük katkı sağlayacağı beklentisidir. Çünkü dördüncü sanayi devrimi, dünyada ihtiyaçları karşılanmamış insanların küresel ekonomi ile bütünleşmesine olanak sağlamakta ve bu da ürün ve hizmetler için talebi artıracak bir unsur olarak ortaya çıkmaktadır. Ayrıca hükümetler, şirketler ve hatta sivil toplum örgütleri de dördüncü sanayi devriminin ortaya çıkarmış olduğu dijitalleşmeye ayak uydurabilecek örgütsel yapılara geçiş sağlama aşamasındadır. (Schwab, 2017, s. 42). Bu durum, dördüncü sanayi devriminin sağlayabileceği potansiyel verimlilik artışlarının henüz tam olarak ortaya çıkmadığını göstermektedir. Endüstri 4.0 ile birlikte inovasyon stratejileri kritik öneme sahip olmuştur. Klaus Schwab bu durumu şöyle anlatmaktadır: "Benim görüşüm dördüncü sanayi devrimi ekonomisinin rekabet kurallarının önceki dönemlerden tamamen farklı olacağı yolundadır. Rekabet güçlerini koruyabilmek için ülkeler ve şirketler bütün biçimleriyle inovasyonun ön saflarında yer almak zorundadır, bu ise öncelikle maliyetleri düşürmeye ağılık veren stratejilerin ürün ve hizmetleri daha inovatif şekillerde sunmaya yönelik stratejilere kıyasla çok daha az etkin olacağı anlamına gelir." (Schwab, 2017, s. 43) Schwab’ın bahsettiği bu inovasyon kültürünün ortaya çıması ise kurumların örgütsel yapılarının dönüştürülmesi ile mümkün olacaktır. 


\section{İstihdam Üzerine Etkileri}

İktisatçı Schumpeter'in yaratıcı-yıkım yaklaşımına göre; teknolojik yenilikler pazarda var olan ürünlere ve örgütsel yapılara alternatif olması durumunda, eskilerini yıkarak onların yerine geçer (Duran ve Saraçoğlu, 2009, s.59). Birinci sanayi devriminden itibaren ortaya çıkan teknolojik yenilikler kısa vadede işsizliği artırsa da uzun vadede istihdamı arttırıcı etkiler ortaya çıkarmıştır. Bir diğer iktisatçı John Maynard Keynes ise; teknolojik gelişmelere karşı uyarısını şu şekilde yapmıştır: “İşgücü kullanımından tasarruf etme araçlarını keşfetmiş olmamız onun için yeni kullanımlar bulma hızına ă̆ır basıyor” (Schwab, 2017, s. 44). Keynes'in bu endişesi teknolojinin kısa dönemde istihdam üzerine olan olumsuz etki ile ilgilidir. Keynes'in bu endişeleri günümüze kadar gerçekleşmemiş olduğu için iktisatçllar bu konuda herhangi bir kaygı içine girmemiştir. Çünkü gelir artışları yeni ürün ve hizmetlere olan talebi arttırmakta ve bu durum işsiz kalan işçilerin; yeni mal ve hizmetlerin üretilebilmesi için ortaya çıkan çalışma alanlarında istihdam edilmesi sonucunu doğurmaktadır (Kazdağlı, 2015, s.2122). Her ne kadar Keynes'in uyarıları bir önceki sanayi devrimlerinde yaşanmasa da dördüncü sanayi devrimindeki teknolojik gelişmelerin üstel boyutlarda ilerlemesi, bu sonucun oluşma ihtimalini ortaya çıkarmıştır.

Dördüncü sanayi devriminin bütün sektörlerde ve mesleklerde çalışma şeklini büyük oranda değiştireceğine kesin gözüyle bakılmaktadır. Ancak, otomasyonun işgücünü hangi miktarda ikame edeceği ve bu ikamenin ne kadar sürede gerçekleşeceği henüz belli değildir. Nitekim teknolojik gelişmelerin istihdam üzerindeki iki etkisine vurgu yapılabilir. Birincisi; teknolojik ilerlemelerle birlikte sermayenin emek yerine ikame edilmesi ve işçilerin işsiz kalmasının ortaya çıkarmış olduğu olumsuz durum iken, ikincisi; yeni ürün ve hizmetlere olan talebin artmasıla yeni işlerin ortaya çıkması ve işçilerin bu yeni iş alanlarında istihdam edilmesinin oluşturduğu olumlu durumdur (Schwab, 2017, s. 44).

Dünya ekonomisinin küreselleşmesi; ortadan kalkan ülke sınırları ile sermaye hareketlerinin serbestleşmesi ve üretimin yer değiştirebilmesi imkânlarını doğurmuştur. Bu durumda, sermaye en çok kar elde edebileceği yerlere gitmeye başlarken, üretimin de en ucuza gerçekleşebileceği yerlerde yapılmaya başlandı. Küreselleşmenin ivme kazandığı 1980'lerden itibaren Amerika Birleşik Devletleri(ABD) ve Avrupa Birliği (AB) gibi gelişmiş ülkeler, üretimlerini ucuz işgücü ve vergi avantajları nedeniyle başta Çin olmak üzere Uzakdoğu ülkelerine kaydırmıştır (Eğilmez, 2017). Küreselleşme sayesinde gelişmiş ülkelerdeki yatırımcılar ucuz işgücünden yararlanarak maliyetlerini düşürürken, gelişmekte olan ülkeler de gelen bu yabancı yatırımlar sayesinde büyüme ve istihdam gibi konularda ekonomik potansiyellerini kullanabilmişlerdir.

Ancak üretimde otomasyonun gelişmesi bu durumu olumsuz etkilemektedir. Çünkü gelişmekte olan ülkelerdeki ucuz işgücünün önemi dördüncü sanayi devriminin getirmiş olduğu imkânlarla ortadan kalmaktadır. Bu ise; gelişmekte olan ülkelerin bu avantajı kaybederek istihdam ve büyüme oranlarında ciddi sıkıntılar yaşayabileceği anlamı taşımaktadır. 


\section{Dış Ticaret Üzerine Etkileri}

Endüstri 4.0 ile beraber dış ticaret yapısı da değişime uğramaktadır. Yaşanan gelişmeler ile birlikte ihracat ve ithalat yalnızca mal ticareti olarak değil veri ticareti ile de gerçekleşmektedir. Bu veriler; E-kitaplar, film ve müzikler, bilgisayar oyunları, teknik çizimler ve bilişim hizmetleri gibi kavramları kapsamaktadır (Kazdağlı, 2015, s.31). Ayrıca Dördüncü Sanayi-Endüstri Devrimi’nnin sağlamış olduğu avantajlar ile üretimin daha inovatif bir şekilde yapılması, ülkelerin birbirleriyle yapmış olduğu ticareti etkilemektedir. Sanayi-Endüstri 4.0 uygulamalarının kullanılabilmesi için yapılan yatırımlar nedeniyle genel üretim maliyetleri artmaktadır. Ancak ileri gelişmiş makinelerin kullanılması ve üretimde otomasyonun daha yaygın hale gelmesi bir önceki bölümde de bahsedildiği üzere işçilik maliyetlerini ortadan kaldırmaktadır. Bununla birlikte; siber fiziksel sistemler ve nesnelerin interneti kavramlarının desteklediği akıllı fabrikalar ile üretim miktarı artmaktadır. Yatırım maliyetlerinin yüksek olması başlangıçta üretim maliyetlerine yansısa da daha sonra uzmanlaşma ve seri üretim ile maliyetlerin düşmesi söz konusu olmakta ve Endüstri 4.0 uygulamalarının etkin bir şekilde kullanılması ülkelerin ihracat performanslarını olumlu yönde etkilemektedir. Bu ülkeler yüksek teknolojili ürünleri ile küresel piyasalarda daha rekabetçi ülke konumuna gelmekte ve böylece ihracat rakamların artırabilmektedir. İhracat rakamlarının artması ülkelerin dış ticaret bilançosunda artı değer sağlamakta ve bu durum ise ülkelerin makro düzeyde GSYH.nın artmasına neden olmaktadır. Ayrıca ihracatın artması, ülkede toplam harcamaları arttıran bir etken olmakla birlikte istihdamı da artırmaktadır (Seyidoğlu, 2013, s.337).

Endüstri 4.0’’n en önemli amaçlarından biri bahsedildiği üzere, üretimde insan emeğinin minimum düzeye indirilmesi ve buna bağlı olarak da üretimin hızlanmasıdır (Eğilmez, 2017). Üretimde insan emeğine olan ihtiyacın her geçen gün azalması ucuz işgücünün önemini azaltmakta ve bu durum küresel ekonomik düzeni etkilemektedir. Endüstri 4.0 uygulamalarını etkin bir şekilde kullanan Almanya, Güney Kore ve Japonya gibi ülkeler üretimdeki yüksek teknolojili ürünleri sayesinde dış ticaret fazlası vermektedirler. Bu gelişmeler küresel piyasalarda ucuz işgücüne sahip olan ve dış ticaret fazlası veren ülkelerin, Endüstri 4.0 uygulamalarını kullanamaması durumunda dış ticaret açığı verebileceklerini göstermektedir.

Dış ticaret açısından; Endüstri 4.0, taşımacılık ve lojistik sektöründe derin değişiklikler yaratarak önemini de arttırmıştır. Endüstri 4.0 kavramı ile mamul-ürün yaşam süresince üretimde yöntem ve tekniklerin yeni bir yolunu tarif edilmekte;

- Ürünler

- Makinalar

- Nesneler ve

- Üretim sürecinde insanlar ve BİT* sistem üzerinde merkezileşmektedir.

Burada ağlar, optimize edilmiş üretim zamanlarına ve bakım döngülerine izin vermenin yanında aynı zamanda, küçük bireyselleştirilmiş miktarların maliyet-etkin üretimini mümkün kılmaktadır. Bu ise küçük, orta büyüklükteki işletmeler ile tüketicilerin istek ve arzularının 
karşılanması anlamı taşımaktadır. Ancak ürün ve tüketicilerin (kişi ve kurum olarak) istek ve arzuları ile ihtiyaçları üretim sisteminin yeniden düzenlenmesiyle her ne kadar giderilmekte ise de; öncelikle mamul-ürünlerin onların kullanımına istenilen yer ve zamanda sunulması daha fazla önem taşımaktadır.

Bu ise; lojistik ve taşımacılığın yapısını ciddi bir biçimde değiştirdiği gibi;

- $\quad$ Potansiyel yeni iş modelleri,

- $\quad$ Last-Mile çözümleri,

- Şehir lojistiği ve

- Tedarik zincirlerinin organizasyonu

üzerine yoğunlaşılmasına neden olmuştur. Özellikle, sınır ötesi işlemlere odaklanan lojistik üzerindeki etki hem talep hem de arz tarafında, makroekonomik, sektörel ve şirket düzeyinde kendisini hissettirmekte olup; dikkatlerin öncelikle, taşımacılık ve lojistik hizmetlerinin (taşımacılık ve lojistik firmalarının) gelecekteki talebinin nitel yönleri ile (endüstriyel şirketler tarafından) ele alınması ve tedarik edilmesine çekmiştir. Uzmanların görüşlerinden elde edilen bulgular ayrıca, yaklaşık 200 ulaştırma şirketi hakkında yapılan standart bir araştırmaya dayanılarak endüstri çapında geçerliliği için kontrol edilmiş ve bunu bu bulguların, endüstriyel, nakliye ve lojistik şirketleri ile ilgili vaka incelemelerinde daha da geliştirilmesi izlemiştir. Sonuçta, Sanayi-Endüstri 4.0 sayesinde lojistik ve taşımacılık endüstrisinin gelişimini şekillendirilmesi söz konusu olup; ortaya çıkan firsatlar (örneğin; Avusturya'nın çok önemli bir Avrupa lojistik merkezi olarak, verimli ve ekolojik olarak ulaşım araçlarını kullanabilmesi vb.) aynı zamanda içerdiği risklerin (sayısallaştırma, rasyonalizasyon için daha fazla firsat, düşük iş kaybı riski, vb.) oluşturduğu bir sistemde ağırlıklı, şeffaf ve odaklanmış bir şekilde sunulmasını mümkün kılmaktadır. Böylece toplumsal, eğitimsel, cinsiyet ve yer politikası önlemleri ile birlikte ekonomik ve ulaştırma politikaları için farklılaştırılmış eylem ve strateji önerilerinin hazırlanması için uygun bir temel oluşturulmaktadır.

\section{Sanayi-Endüstri 4.0 Devrimi’nin İşletmeler Üzerine Etkileri}

Dördüncü Sanayi devrimi ile ortaya çıkan teknolojiler, şirketlerin yönetim, örgütlenme ve kaynak bulma yöntemlerini önemli ölçüde etkilemektedir. Ayrıca dijital destekli yeni teknolojiler, şirketlerin değişim hızını ve boyutunu artırmaktadır (Schwab, 2017, s.59). Dördüncü Sanayi devrimi, şirketleri çeşitli teknolojileri bir araya getirmeye zorlamakta ve karmaşık bir inovasyon sisteminin ortaya çıkmasına neden olmaktadır. Bu durum, şirketleri geleneksel iş yapma yöntemlerini değiştirmeye ve sürekli inovasyon yapmaya zorlamaktadır (Schwab, 2017, s.61). Geleneksel iş yapma yöntemlerini değiştirebilen ve inovasyon ortamı yaratan şirketler, bir taraftan mevcut durumlarını korumakta, diğer taraftan ise kârlılıklarını artırmaktadır. Buna karşılık inovasyon ortamını sağlayamayan firmalar ise yok olma tehlikesiyle karşı karşıya kalabilmektedir. 
Bilgi, işletmelerin karar alma aşamasında var olan en önemli kaynaklardan biridir (Al, 2013, s.189). Dördüncü Sanayi devrimi ile daha da önemli hala gelen bilgi, şirketler tarafından içselleştirilmeli ve içselleştirilen bu bilgiler karar alma aşmasında verimli bir şekilde kullanılmalıdır. Ayrıca, şirket yöneticilerinin bulundukları şirketin öğrenme ve buna bağlı olarak, değişme kapasitesine, hızlı yatırım kararlarını alma potansiyeline sahip olup olmadığına bakması bir zorunluluk olarak kabul edilmektedir (Schwab, 2017, s.60).

Accenture firmasının yapmış olduğu tahminler, 2020 yllına gelindiğinde endüstriyel nesnelerin interneti sektörüne yapılan yatırımların 500 milyar dolar civarında olacağı yönündedir (Soh ve Unkefer, 2014). Nitekim bu yatırım ortamında sistem dışında kalan firmalar, yatırım imkânlarından yararlanamayacak ve dönüşümün dışında kalacaktır (Özdoğan, 2017, s. 42). Eskiden değer yaratma işletme içinde sağlanırken, günümüzde şirketlerin müşterilerle olan etkileşimi ile sağlanmaktadır (Banger, 2017, s.187). Dijitalleşme; müşterilerin bilgiye daha hızlı ve kolay biçimde ulaşmasını sağlamakta ve bu doğrultuda müşteri taleplerinin de değiştiği görülmektedir. Şeffaflığın artmasına neden olan dijital ortam sayesinde tüketiciler daha çok veriye sahip olmakta, ürünler hakkında daha fazla karşılaştırma yapma fırsatı bulmaktadır. Buna bağlı olarak şirketler önceki zamanlara göre, müşterilere daha fazla hesap verme sorumluluğu altına girmek zorunda kalmakta olup; şeffaflaşma arttıkça bu sorumluluk daha da büyüyecektir (Schwab, 2017, s. 63).

Cisco Internet Business Solutions Group, 2020 yllına kadar 50 milyar cihazın internete bağlanacağını tahmin etmektedir (Evans, 2011). Tüketicilerin daha fazla internete bağlı cihazlara sahip olması, tüketici verilerinin şirketlere aktarımını kolaylaştıracak ve bu da şirketlere bu veriler sayesinde kişiye özel teklif yapabilme olanağını sunması ile birlikte (Büyük ve Öz, 2017, s.51). Dördüncü Sanayi devriminin getirmiş olduğu imkânlarla çeşitli alternatifler sunma olanaklarını arttıracaktır.

İnternetin yaygınlaşmasıyla birlikte veri üretiminin artması ve işletmelerin artan veriler üzerinde çalışmasıyla yeni bakış açıları ortaya çıkarak ve yeni pazarlara açılma şansına kavuşulmuştur. Bir diğer ifadeyle, Dördüncü Sanayi Devriminin en önemli bileşeni olan inovasyon yeni ürünler yoluyla yeni pazarların oluşturulmasına olanak sağlamaktadır (Banger, 2017, s.193).

Müşteri isteklerinin değişmesi, veriye dayalı hizmetler ve varlık performansının analiz edilebilmesi, şirketleri yeni iş birliklerine zorlamaktadır. Bu durum, hem yerleşik firmalar hem de genç firmalar için de geçerlidir. Genç firmalar, yerleşik firmalara göre daha az sermeye ve veriye sahiptir. Yerleşik firmalar ise; yenilikçi becerileri daha az olduğu için, genellikle müşteri taleplerinin değişmesine daha geç vermektedir. (Schwab, 2017, s. 65). Bu durum da şirketlerin iş birliği ortamı sağlamasına neden olmaktadır.

Dünya Ekonomik Forumu’nun "İşbirlikçi İnovasyon: Şirketleri Dönüştürmek, Büyümeyi Güçlendirmek" adlı raporu; şirketlerin ortaya çıkardığı işbirlikçi inovasyonların, tüm taraflara ve iş birliğinin içinde bulunduğu ekonomiye önemli katkılar sağladığını göstermektedir. Örneğin; önde gelen sanayi firmalarından Siemens ile inovatif bir makine öğrenme şirketi Ayasdi ve 
Stanford Üniversitesi'ndeki Forum Technology Pioneer bir iş birliği içine girmişlerdir. Bu iş birliği, Siemens’e elde edilen verilerden sonuç çıkarabilen bir ortak sağlarken, Ayasdi firmasına da pazar varlığını genişletme şansı vermiştir (Schwab, 2017, s.66).

MIT Sloan Yönetim Okulu’nun yaptığı araştırmaya göre; piyasa değeri bakımından önde gelen 30 firmanın 14'ünün platform yönelimli şirketler olduğu görülmekte olup; bunlar arasında Akamai, Linkedln, Airbnb ve Uber gibi şirketler yer almaktadır (MIT, 2014). Platform stratejileri de birçok sektörde ürün satmaktan ziyade hizmet sunmayı ön plana çıkarmaktadır. Tüketiciler, dijital ortamda erişim sağlayabilecekleri hizmeti, fiziksel ürünleri almaya tercih etmektedir. Örneğin; Tüketiciler Amazon Kindle cihazı sayesinde dijital ortamda kitaplara erişebilmekte ya da Spotify sayesinde birçok müziği dinleyebilmektedir (Schwab, 2017, s. 67). Bu gibi örneklerde geleneksel firmaların bu değişime ayak uydurabilme kapasitelerini arttırma gerekliliğini ortaya koymaktadır.

Sanayi-Endüstri 4.0 temelinin İnsan-Makine Işs birliği üzerine kurulması ile özellikle yukarıda açıklanan yararlar dişında tüm işletmeler, ortaya çıkan somut gelişmelerin kuramları ve uygulamalarıyla ilgili olarak bir sanayi devriminin ortasında bulunmaktadır. Bu aşamada, daha önceki analog tekniklerin sayısallaştırılması ve sibermatik sistemlerin entegrasyonu üzerine odaklanılmakta olup, buna bağlı olarak da uzun yıllardan sonra birçok şirket (işletme) stokta üretim yapmayı bırakmış, talep üzerine veya gerçek ihtiyaçlarına göre birçok ürün üretmiştir. Tam zamanında stratejiler, bilgi işleme ve teknolojideki sürekli gelişme sayesinde uygulanabilmekte ve her zamankinden daha hızlı üretime ek olarak, çevre koruması ve iş güvenliği alanında yeni ilerlemelerin kaydedilmesine olanak yaratmaktadır (Industrie Wegweiser).

Ayrıca, Sanayi-Endüstri 4.0, aracılığıyla hızla değişen gelişmelere etkisindeki tüketici istek ve eğilimleri, zevkleri ve ihtiyaçlarına oldukça geniş bir model ve tasarım yelpazesine sahip üretimle, üretilecek yüksek kaliteli mamul/ürünlerle daha hızlı ve daha hassas yanıt verilebilecektir. Çünkü günümüz ve geleceğin üretim faaliyetlerinde dijitalleştirme yoluyla otomasyon artmaktadır ve robotlar ile insanlar birlikte çalışacaklardır (Jann Raveling, 2017).

\section{Sanayi-Endüstri 4.0 Devrimi Ve Türkiye}

Türkiye, coğrafi konumunun vermiş olduğu lojistik avantajı ve görece düşük maliyetli iş gücü sayesinde küresel ekonomide önemli bir rekabetçi ülke konumunda bulunmaktadır. The Boston Consulting Group (BCG) Global Üretim Maliyetleri Endeksi'ne göre; Almanya 121, ABD 100 ve Türkiye 98 ortalama birim maliyeti ile üretim yapmaktadır. Bu durum, Türkiye’nin ihracatını arttırabilmek için sahip olduğu rekabet avantajını göstermektedir (TÜSİAD ve BCG, 2016, s.33). 


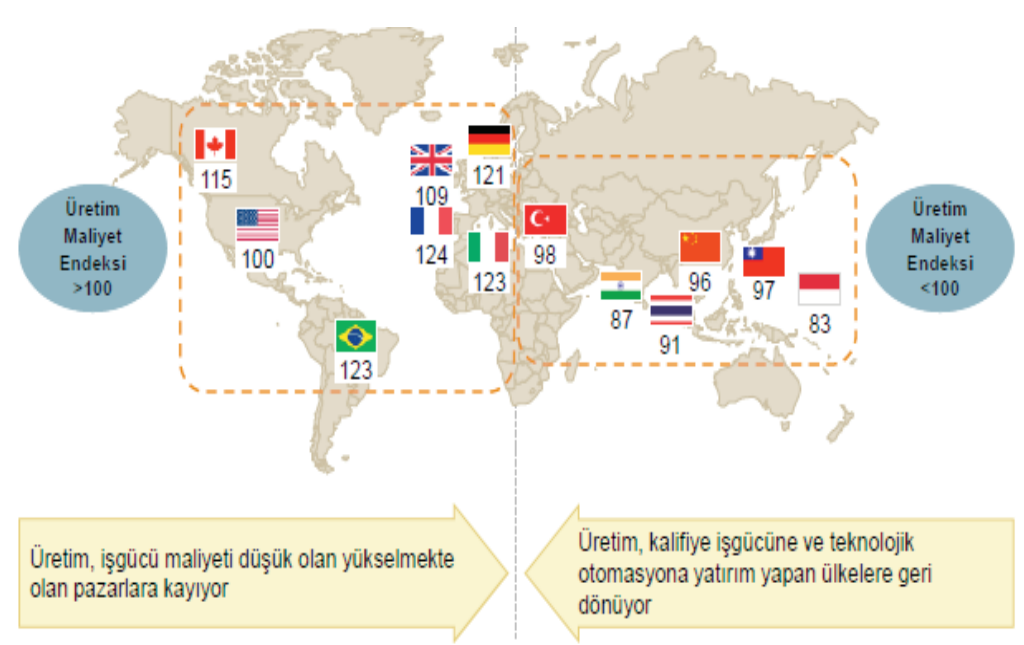

Kaynak: TÜSİAD ve BCG, 2016, s.33.

Şekil 2. Global Üretim Maliyet Endeksi, 2014.

Sahip olduğu bu avantajların yanında Türkiye ihracatının ithalata bağımlı halde olması, toplam üretim içindeki katma değerli üretim payının düşük olması, eğitim seviyesine bağlı olarak işgücü becerilerinin istenilen düzeyde olmaması gibi dezavantajları da bulunmaktadır. Türkiye’nin ihracat yapısı incelendiğinde; gelişmiş ülkeler ile kıyaslandığında sanayi ürünleri ihracatında yüksek teknolojili ürünlerin ihracatının çok düşük olduğu görülmekte olup; bu durum aşağıda tablo 1'de gösterilmiştir.

Tablo 2. Ülkelerin Toplam İmalat Sanayi Ürünleri İhracatında Yüksek Teknolojili Ürünlerin \% Payı

\begin{tabular}{|l|l|}
\hline Ülkeler & Sanayi ürünleri ihracatında yüksek teknolojili ihracatın yüzdelik payı (2015) \\
\hline Fransa & 26.8 \\
\hline G. Kore & 26.8 \\
\hline Çin & 25.8 \\
\hline ABD & 19.0 \\
\hline Japonya & 16.8 \\
\hline Almanya & 16.7 \\
\hline Kanada & 13.8 \\
\hline Rusya & 13.8 \\
\hline Brezilya & 12.3 \\
\hline Hindistan & 7.5 \\
\hline G. Afrika & 5.9 \\
\hline Türkiye & 2.2 \\
\hline
\end{tabular}

Kaynak:World Bank Data 
Bu durum, Türkiye’nin imalat sanayi ihracatının, ağırlıklı olarak düşük ve orta teknolojili ürünlerin ihracatıyla gerçekleştiğini ve yükselen orta ölçekli ekonomiler arasında yer alan Türkiye, bu devletler ile kıyaslandığında sanayi ürünlerinin toplam ihracatı içindeki yüksek teknolojili ürün ihracatının yeterli seviyede olmadığı görülmektedir. Şu halde; bu oranın artırılabilmesi durumunda Türkiye’nin küresel piyasalarda çok daha önemli bir rekabetçi ülke konumuna yükseleceği görülmektedir.

Tablo 3: Dünya’daki Bazı Seçilmiş Ülkelerin Ve Türkiye’nin AR-GE Harcamalarının GSYH İçindeki Payı

\begin{tabular}{|l|l|}
\hline Ülkeler & AR-GE Harcamalarında GSYH İçindeki Payı (2015) \\
\hline Güney Kore & 4.2 \\
\hline Japonya & 3.3 \\
\hline Almanya & 2.9 \\
\hline ABD & 2.8 \\
\hline Fransa & 2.2 \\
\hline Çin & 2.1 \\
\hline Türkiye & 1.0 \\
\hline
\end{tabular}

Kaynak: World Bank Data

Ayrıca; dördüncü sanayi devrimi ile birlikte diğer ülkelerin üretim verimliliklerinde ortaya çıkabilecek artışlar, Türkiye'nin küresel anlamda rekabetçiliğini düşürebilme ihtimalini doğurmaktadır (TÜSİAD ve BCG, 2016, s.34). Endüstriyel gelişmelere karşı rekabetçiliğin korunabilmesi ve üretim verimliliğinin arttırabilmesi için AR.-GE yatırımları ve çalışmaları oldukça önemlidir (Yazıcı ve Düzkaya, 2016, s. 75). Görüldüğü gibi, Türkiye AR.-GE harcamaları bakımından da düşük seviyede kalmıştır. 2015 TÜİK verilerine göre Türkiye; GSYH’nın sadece \%1.06’sı kadar AR - GE harcamalarına pay ayırabilmiştir. Burada özellikle \%4.2 oranı ile Güney Kore dikkat çekmektedir. Çünkü 1980'li yıllarda kişi başına düşen milli gelir harcamaları açısından Türkiye ile neredeyse aynı seviyede olan Güney Kore, uygulamış olduğu kalkınma politikaları ve bu doğrultuda yapmış olduğu AR-GE faaliyetleri ile ciddi anlamda kalkınma sağlayabilmiş ve küresel piyasalarda önemli bir aktör haline gelmiştir.

AR-GE destekli ve yenilikçi üretim yerine, geleneksel üretim tarzının benimsenmesi ve buna bağlı olarak katma değerli ürünlerin üretilememesi nedeniyle bir ülkede belirli bir seviyeye ulaşan kişi başı milli gelirin, o seviyeyi aşamaması ve ülkenin gelişmiş ülke kategorisine ulaşamaması, orta gelir tuzağı olarak ifade edilmektedir (Çeliktaş ve Sonlu, Özgel ve Atalay, 2015, s.31) 
Tablo 4. Türkiye’nin Yıllar İtibariyle Kişi Başına Düşen Milli Geliri

\begin{tabular}{|l|l|}
\hline Ylllar & Kişi Başına Düssen Milli Gelir (\$) \\
\hline 2002 & $3.580,7$ \\
\hline 2003 & $4.697,6$ \\
\hline 2004 & $5.960,9$ \\
\hline 2005 & $7.304,4$ \\
\hline 2006 & $7.905,8$ \\
\hline 2007 & $9.655,9$ \\
\hline 2008 & $10.930,6$ \\
\hline 2009 & $8.979,8$ \\
\hline 2010 & $10.559,8$ \\
\hline 2011 & $11.205,2$ \\
\hline 2012 & $11.587,8$ \\
\hline 2013 & $12.480,4$ \\
\hline 2014 & $12.112,4$ \\
\hline 2015 & $11.018,9$ \\
\hline 2016 & $10.882,5$ \\
\hline
\end{tabular}

Kaynak: TÜİK

Türkiye’nin AR-GE harcamalarının düşüklüğü ve buna paralel olarak imalatta yüksek teknolojili üretimin düşük seviyelerde kalması önemli bir sorun olarak karşımıza çıkmaktadır. Tablodan da görüldüğü gibi; 2008 küresel krizine kadar yüksek büyüme ivmesi kazanan Türkiye’nin sonraki yıllarda bu durumu istenilen seviyelerde sürdürememesi bu sorunu açıkça göstermektedir.

Türkiye’nin 2023 yılında ilk 10 ekonomi arasına girme hedefini gerçekleştirebilmesi için yılda ortalama \% 8.5 büyümesi gerekmektedir (Ersoy, 2017). Endüstri 4.0 çağında geleneksel üretim metotları ile bu büyüme rakamlarına ulaşmak ise; neredeyse imkansızdır.

BCG. analizine göre; Sanayi-Endüstri 4.0’’ uygulamaya başlayan Almanya'da üretim maliyetlerinin $\% 5$ ile \%8 düşmesi ile birlikte, önümüzdeki 10 yıl içinde 90 ile 150 milyar Euro arasında verimlilik kazancının gerçekleşeceği tahmin edilmektedir. Ayrıca malzeme maliyetlerinde de \%20 düşüş beklenmektedir. Bununla birlikte, şirketlerin ileri teknolojili ürünlere, tüketicilerin ise; özelleştirilmiş ürünlere olan talebinin artmasıyla 300 milyar Euro ek gelir sağlanacağı ve büyümedeki bu artışında istihdama \%6’lık katkı sağlayacağı beklenmektedir (TÜSİAD ve BCG, 2016, s.35). Eğer Almanya Endüstri 4.0 uygulamalarını başarılı bir şekilde sürdürür ve Türkiye mevcut rekabet koşullarında gelişme sağlayamaz ise; Almanyaya kıyasla sahip olduğu rekabet avantajının büyük bir oranını kaybedebilir. Sonuç olarak; Sanayi-Endüstri 4.0 ile üretim maliyetleri yüksek olan ülkeler, ileri teknolojiye sahip işletmelerindeki geniş ölçeği kullanarak; düşük üretim maliyetine sahip ülkeler ise yeni teknolojilere daha kolay erişme olanaklarını kullanarak küresel arenada rekabet pozisyonlarını güçlendirecektir ( TÜSİAD ve BCG, 2016 s.36).

$\mathrm{Bu}$ durumda, Türkiye’nin uluslararası arenada rekabet koşullarını koruyabilmesi hatta güçlendirebilme için Sanayi-Endüstri 4.0 yatırımlarını en etkin biçimde gerçekleştirmesi 
gerekmektedir. Sanayi-Endüstri 4.0 yatırımlarının etkin bir şekilde uygulanabilmesi için nitelikli işgücüne ihtiyaç duyulmaktadır. Türkiye'deki nitelikli işgücünün yeterli olmayışı da eğitim politikalarının önemini göstermektedir. OECD’nin Uluslararası Öğrenci Performansı Değerlendirme (PISA) 2015 raporlarına göre; Türkiye bilim, matematik ve okuma becerilerinde 72 ülke arasında 50. sırada yer almaktadır. Bu durum Türkiye'de eğitim politikalarının yetersiz olduğunu açıkça göstermektedir (Avşar, 2016, s.22).

Scheer Danışmanlık ve Bilgi Sistemleri Genel Müdürü Çağrı Tolga Avşar bu durumu şöyle açıklamaktadır;" Ülkemiz için Dördüncü Sanayi Devriminde başarılı olmanın yolu eğitimden geçiyor. Aksi takdirde gelişmiş ülkelere göre düşük olan işgücü maliyetimizin ve üretkenliğimizin anlamı kalmayacak."

Türkiye'nin küresel anlamda rekabet gücünü koruyabilmesi hatta artırabilmesi için; bu handikapları ortadan kaldırması gerekmektedir. Bu dezavantajları kaldırması durumunda ise küresel ekonomide daha da rekabetçi konuma gelme şansına sahip olacaktır. Türkiye’nin endüstri 4.0 uygulamalarını başarılı bir şekilde yerine getirmesi durumunda üretim sektöründeki verimliliğin \%4 ile \%7 arasında olabileceği düşünülmektedir. Gelir artışlarını hesaplamak tam olarak mümkün olmasa da kazanılacak rekabet avantajı ile sanayi üretiminde yıllık yaklaşık olarak \%3’lere kadar artış beklenmektedir (TÜSİAD ve BCG, 2016, s.44-45).

Türkiye'nin rekabet gücündeki ve katma değerli ürün üretmedeki olası artışlarının, ekonomik büyümeyi ve buna bağlı olarak istihdamı önemli seviyede artırması beklenmektedir. Önümüzdeki süreçte niteliksiz işçi ihtiyacında azalma beklenirken, yüksek nitelikli çalışan ihtiyacının artacağı düşünülmektedir. Bununla birlikte, sanayileşmenin ortaya çıkardığı büyüme artışının yeni iş imkânları yaratacağı öngörülmektedir. Dördüncü sanayi devrimi ile sağlanabilecek \%2-3’lük büyüme oranın, istihdam kayıplarını da telafi edebileceği ve hatta istihdama \%5'lik bir katkı sağlayacağı tahmin edilmektedir. Buna ek olarak, nitelikli işgücü sayesinde de Türkiye’nin gelir seviyesi yükselecektir (TÜSİAD ve BCG, 2016, s.46).

\section{Sonuç}

Dünyamız bugüne dek; siyasal, sosyal, ekonomik, kültürel, eğitsel ve hukuksal açılardan birçok süreçten geçerek değişik evrimler yaşamıştır. Özellikle ekonomik alanda yaşanan üç büyük Sanayi-Endüstri Devrimleri dünyanın tümünü etkilemiş ve Sanayi-Endüstri 4.0 politik ve sosyolojik tartışmalarının başlamasına neden olmuştur. Tartışmaların ortak bir terimi olarak Sanayi-Endüstri 4.0 hayatı kolaylaştıracak, ekonominin dijital hale getirildiği, mikro düzeyde işletmelerin makro düzeyde ülkelerin en azından ortak argümanları olan süreçlerinin ağa bağlandığı en önemli ve ekonomik bir değişikliktir. Öte yandan iş ve toplumsal yaşamı değiştiren Sanayi-Endüstri 4.0 “İnsan Olmayan Makineler-Yarı İnsan Yarı Makine” ile kendinden önce gerçekleşen tüm sanayi devrimlerini de unutturmuştur. Esasını insan-makine işbirliğinin sağlanması üzerine kuran Sanayi-Endüstri 4.0 yolculuğunun IoT yol haritasında yer alan Bilgi Teknolojisi / Bilgi Yönetimi altyapı değişikliklerinden, siber fiziksel 
sistemlerle yürüyen bir "Akıllı Fabrika" yapılandırmasına kadar farklı boyutlarda birçok projeye yer verilmekte, risklerden arındırılmış ve etkin üretimin gerçekleştirilmesi amaçlanmaktadır. Bunun için; yapılan olgunluk-üretkenlik ve verimlilik analizlerinde öncelikle;

- Akıllı Tedarik Zinciri

- Akıllı Üretim Teknolojileri

- Mevcut Bilgi Teknolojileri Sistemleri

- Büyük Veri Kullanımı

- Nesnelerin İnterneti Kullanım Yetkinlikleri

- Organizasyon Kültürü

İrdelenmekte olup, geleceğe yönelik stratejik tercihlerinin belirlenmesi ile piyasanın istek ve ihtiyaçlarının giderilmesi araştırmaları gerçekleştirilmektedir.

Bununla birlikte, bu hızlı değişmelere bağlı olarak belki de yakın bir gelecekteki bir fabrikada insan ve makine arasındaki iletişim, akıllı telefonlarımızdan da bildiğimiz gibi daha "İnsan" haline gelecektir. Buna bağlı olarak da; Sanayi-Endüstri 4.0’ın hem küresel ekonomik faaliyetleri hem de ulusal ekonomik faaliyetleri etkileyerek değişik yarar ve sakıncalar ortaya çıkarmaktadır. Henüz tüm dünyada uygulanamamış ve geleceğe yönelik olması nedenleriyle makro açıdan büyüme, istihdam ve dış ticaret üzerindeki etkilerini kısmen de olsa irdelemek mümkün olmakta olup;

makro açıdan etkileri şunlardır:

a) Büyüme; Yeni teknolojilerle, mamul üretim biçiminin değişmesi ve çeşitlendirilmesi bir yandan nispeten istikrarlı öte yandan kitle üretiminin gerçekleştirilmesi ile büyük bir katma değer yaramakta ve buna bağlı olarak da devrim niteliğinde bir ekonomik büyüme artı̧ı yaşanmaktadır. Örneğin Endüstri 4.0'ın lokomotifi olan ve dünyanın en gelişmiş ekonomilerinden birisine sahip Almanya bu gücü ve sanayi üretiminin katma değerinin yüksekliği ile küresel ağın yeni olanaklarını ulusal olarak etkin ekonomik etkilere dönüştürmekte sağladığı büyüme artış ile küresel rekabet bağlamında ön plana çıkmaktadır. Almanyảnın bu durumu diğer büyük ekonomilere sahip ülkelerle, başta Çin ve Japonya ile ekonomik işbirliğini arttırmasına da olanak sağlamakta ve her geçen gün ekonomik yönden büyümekte ve gelişmektedir. Aynı durum Çin için de geçerlidir ve Çin'de geçtiğimiz son 10-15 yılın en önemli ve en büyük büyüme artışları gerçekleştirilmiş olup; özellikle 2015 yllından itibaren Endüstri 4.0’’n etkileri görülmeye başlanmıştır. Bunda Çin Hükümetinin "Çin Malı Ucuz ve Kalitesizdir" eski imajının yerine" Çin Malı Kalitelidir Ama Daha Ucuz" anlayışı bulunmaktadır.

b) İstihdam; işgücü piyasası ve istihdam açısından bilgi ve teknolojinin arttırılması konusundaki zorluk, yüksek yatırımlardır. Uzun vadede yatırımın güvenliğini sağlamak için standardizasyona ihtiyaç duyulmasının yanı sıra, sık sık yüksek nitelik gerektiren çalışanların 
taleplerinin karşılanmasında da sorunlar doğabilmektedir. Böylece, değişen çalışma koşullarını karşılamak için ek eğitim ve öğretim, bilgi ve beceri geliştirilmesi ekip çalışmasına yatkınlık, feraset ve benzeri özelliklere sahip; nitelikli işgücü gereksinimi yükselirken öte yandan makine mühendisleri yerine yazılım geliştiricileri veya elektrik mühendisleri yerine otomasyon teknisyenleri gibi eğitim mesleklerinde de değişiklikler söz konusudur. Giderek daha karmaşılaşan sistemler, veri selinin kontrol altına alınabilmesi için büyük ve detaylı planlama ve açıklayıcı modeller gerektirmekte, geleceğin iş dünyasında dahi, insan üretimi en önemli faktör olarak kalmaktadır. Çalışanların potansiyelleri siber-fiziksel sistemlerin tasarımı, uygulanması ve ekonomik kullanımı açısından önemli bir rol oynayacaktır. İnsan, makine ve sistem arasındaki etkileşimde değişiklikler olmasına rağmen, çalışanlar planlama, kontrol etme ve yürütme kabiliyetlerinin taşıyıcıları olarak kalmaya devam etmektedir. Bu gelişme ile istihdam artışı sağlanacak, yeni işler ve meslekler ile iş sahaları yaratılacaktır. Buna paralel olarak; şirket çalışanlarının giderek makineler ve sistemler ile çalışması gerektiği için sağlık risklerine maruz kalmamalarını sağlamak için dikkatli olunmalıdır. $\mathrm{Bu}$, örneğin, bir robotla çalışırken, çalışanların karmaşık sistemler ve bilgi birikimi nedeniyle aşırı yük altında kalması ya da bunaltıcı olması ya da insanların, teknik sistemler tarafından harici olarak kontrol edildiği düşüncesini de ortaya çıkarabilir. Ayrıca veri koruma ile ilgili önlemler alınmalı yeni teknolojiler sağlık koruma açısından yeni kapılar açttğı ve bunun fiziksel stresin hafifletilmesine ve sağlık hasarlarının önlenmesine yardımcı olabileceği asla unutulmamalıdır. Otomasyon, insanoğlunu çok uzun zamandır büyülemiş olup; SanayiEndüstri 4.0 da çok öneme haizdir. Otomasyonun herhangi bir aşamasında olduğu gibi, Endüstri 4.0'da teknoloji ile insanlar arasındaki ilişkiyi belirlemektedir düşüncesi genellikle her zaman, verimlilik ve performans artışı sağlamasına karşlık, olumsuz etkiler de yaparak teknolojik işsizlik ve sınıflandırma sorunları yaratabilmektedir.

c) Dış ticaret; Ülkelerin fabrikalarındaki akıllı robotlar, ofisteki akıllı teknoloji ile veri ve bilgi, yeni iş modelleri için potansiyel yaratan "hammadde" haline dönüşmüş olup, bu dönüşüm üretim tesislerinde değil, üretim sistemlerinin akıllıca birbirine bağlanması ile gerçekleştirilmiştir. Bu durum ülkeler açısından geçerli olup; tüm ülkelerdeki iletişimde bir işletmenin tüm sistemlerinin aynı zamanda, üretim değer akış zincirinde; tedarikçilerden başlayarak müşteriler kadar oluşan alt sistemlerindeki gibidir. Bunun yanı sıra işletmelerde tasarım ve mühendislik (ürün ve üretim sisteminde) ile hizmet değer zincirinde (ürün kullanımdayken) iletişim sürmektedir. $\mathrm{Bu}$ açıdan ülkelerin birbirlerini tanımaları aralarındaki mevcut iletişim sistemlerine bağlı olarak tüm üretim ve hizmet süreçlerinde veri ve bilgi, mamul ve hizmet ve tüm ekonomik değer alışverişini hızlandırmaktadır. Ayrıca buna bağlı olarak lojistik ve taşımacılık sektöründe oluşan gelişmeler ve aynı zamanda, ülkeler arası gerekli internet altyapısını oluşturmak için, bilhassa yazılım ve hizmetler alanında, bilgi teknolojisinde giderek daha fazla yeni iş yaratılması da dış ticareti etkilemektedir ve büyümesini sağlamaktadır. Büyüme mal ve hizmet akışları ile finansal kaynakların değişimi biçiminde ortaya çıkmakta ve ülkelerin gelirleri üzerinde olumlu bir etki yaratmaktadır. 
Öte yandan ulusal ekonomiler açısından tüm gerçek ve tüzel kişiler ulusal ya da uluslararası işletme olsun faaliyetleri açısından etkilenmiş olup; tümüyle olumlu etkilenmeden söz edilememektedir. Bunun nedeni Sanayi-Endüstri 4.0’nn henüz çok yeni olması, uygulama sahasının her gün gelişmesine ve bu hususta çeşitli bilimsel çalışmaların ortak iş birliği anlaşmalarının yapılmasına rağmen, işletmelerdeki iş yapılarının uygun olmayışıdır. Şöyle ki; planlama aşamasından uygulama aşamasına ve satın alma aşamasından satış aşamasına kadar yeniden düzenlenmiş olmakla birlikte, birçok şirket hala fayda ve potansiyel konusunda hem fikir görünmemektedir.

Sanayi-Endüstri 4.0'ın mikro düzeyde-işletmeler üzerinde yarattığı değişim ve gelişmeler şunlardır:

- Yönetim açısından; imaj yükseltilmesi, misyon ve vizyonun geliştirilerek süreklileştirilmesi, organizasyonun geliştirilmesi ve takım çalışmasının ön plana çıkarılması, çalışanların memnuniyetlerinin yükseltilmesi,

- Finansal açıdan; işletme varlı̆̆ının ve ödeme gücünün korunarak büyümenin ve karın arttırılması, sermaye çekilmesi ve yeni yatırımların yapılması, ortak ve hissedarlara daha fazla kâr payı verilmesi,

- Maliyet açısından; tüm maliyetlerin kontrolü ve azaltımı ile, daha düşük maliyetli ancak daha kaliteli ve uygun fiyatlarla satılabilir mamul-ürün üretiminin gerçekleştirilmesi,

- Üretim açısından; üretimde insan makine iş birliğinin sağlanması ve kütle üretiminin arttırılması, bir diğer ifade ile; etkenlik ve üretkenliğin yükseltilmesi, optimal üretimin gerçekleștirilerek sürekliliğinin sağlanması,

- Satış ve Pazarlama açısından; üstün rekabet gücüne kavuşularak pazar payının arttırılması ya da pazara egemen olunması, müşteri istek ve gereksinimlerin hem kalite hem de fiyat olarak istenildiği gibi karşılanması ve satış sonrası hizmetlerin (servis, dağııım, yedek parça ve değişimi hizmetleri) ve her tür faaliyetlerin geliştirilmesi,

- Araştırma Geliştirme faaliyetlerine daha fazla önem verilerek, BİT. (Bilgi ve İletiş̧im Teknolojileri) den daha fazla yararlanmak, inovasyona daha fazla önem verilmesi gibi yararları vardır.

Birçok yeni firsatları sunan; Dördüncü Sanayi-Endüstriyel Devrim'in temel unsuru Akıllı Fabrikanın Gelecek Vizyonudur. Çeşitli sistemler üretim, mühendislik, yönetim ve internet servislerinin sayısız süreçlerini bir araya getirir. Sensörler vasıtasıyla bilgi alışverişi yapılır ve bu eylemler tetiklenebilir. Sanayi-Endüstri 4.0 demografik değişim yönetimini desteklemektedir çünkü işin demografik yapısının hassaslaştırılması ve yükü hafifletilmesi mümkündür. Ayrıca, daha uzun bir çalışma ömrü olan yaşlı çalışanların verimliliği de korunabilir. Teknoloji yaratıcı işler personel tarafından yapılabilirken hem ağır hem de monoton işler yapabilir. Çalışanların iş ve özel yaşamlarını kendi isteklerine göre uyarlamaları için rekabetçi bir çalışma gereklidir. Bir şirket, iş ve aile arasında sağlıklı bir denge sunarak çekiciliğini artırır. Bu açıklamalardan da 
görüleceği gibi çok sayıda fayda ve fırsatlara ek olarak, Endüstri 4.0 de profesyonel süreç için zorluklar görülmektedir. Günlük işler, büyük ölçüde çalışanlarını etkileyen temel değişikliklerle karşı karşıya olup;

“Tüm bu gelişmelerin sonucunda gelecekte işimiz hala devam edecek mi?” sorusu henüz yanıtlanamamış olup; en önemli sorun olarak karşımıza çıkmaktadır. Çünkü insan araç değil amaçtır. Bununla birlikte işgücü, para ve zamandan tasarruf ve maliyetlerin azaltılması, mamul kalitesi ve verimliliğin yükseltilmesi, gelir artışlarının arttırılması hem makro hem de mikro düzeyde gözlenebilir.

$\mathrm{Bu}$ yönleriyle değerlendirildiğinde; Sanayi-Endüstri 4.0 diğer sanayi devrimlerine göre kendi içinde birçok farklılık barındırmaktadır. Bu farklardan en önemlisi hız faktörüdür. Diğer sanayi devrimlerinde doğrusal olarak ilerleyen teknolojik gelişmeler dördüncü sanayi devrimi ile birlikte üstel bir hızla ilerlemektedir. 2000'li yıllardan itibaren tarihte daha önce hiç kaydedilmemiş hızda teknolojik gelişmeler yaşanmakta ve bu gelişmeler dijitalleşme temeli üzerinden ilerlemektedir.

Dördüncü sanayi devrimi, sanal ve fiziksel imalat sistemlerinin iş birliğini içermektedir. Diğer sanayi devrimleri göz önüne alındığında Endüstri 4.0’’n en önemli farkının çeşitli teknolojilerinin karşılıklı olarak etkileşime geçmesidir. Buna bağlı olarak da üretim şekilleri ve boyutları ciddi anlamda değişmekte ve karmaşık hale gelmektedir.

Dördüncü sanayi devrimi köklü paradigma değişimlerini de beraberinde getirmektedir. İnovasyon kültürünün yayılması ile birlikte hükümetler, özel sektör ve hatta toplumun tüm katmanları zorunlu olarak bu paradigma değişimine ayak uydurmaktadır.

Siber fiziksel sistemler ile üretim sürecinin otomatik olarak gerçekleştiği akıllı fabrikaların ortaya çıkarması, yapay zekâ teknolojisi ve makineler arası etkileşimin sağlanması, üretimi daha kolay hale getirmektedir. Bununla birlikte üretimde insan emeğine olan ihtiyaç da giderek azalmaktadır.

Üretimde insan emeğine olan ihtiyacın azalmasının hem ülke ekonomilerini hem de küresel ekonomiyi hangi boyutta etkileyeceği tartışma konusu olmaktadır. Çünkü dijitalleşme temelli üretimdeki otomasyonun, ülkelerdeki istihdam verilerini ciddi anlamda etkileyeceği öngörülmektedir. Ayrıca, küresel ekonomide ucuz işgücü sayesinde rekabet avantajı sağlayan başta Uzakdoğu ülkeleri olmak üzere, Türkiye gibi gelişmekte olan orta ölçekli ülkeler, işgücüne olan ihtiyacın azalmasıyla bu avantajını kaybetme tehlikesiyle karşı karşıya kalmaktadır. Nitekim bu ülkelerin global ekonomide rekabet avantajlarını koruyabilecek farklı stratejiler geliştirmek zorunda oldukları açıktır.

Yaşanan gelişmelerle birlikte niteliksiz işgücüne olan ihtiyaç azalırken, nitelikli işgücüne olan ihtiyaç artacaktır. Bu bağlamda, Türkiye de sahip olduğu genç nüfus ile küresel anlamda Endüstri 4.0 gelişmelerini lehine çevirebilme potansiyeline sahiptir. Çünkü dördüncü sanayi devrimi, bilgi ve iletişim teknoloji temel alan bir zemin üzerine kurulmuştur. Genç nüfusun bu temeller üzerine eğitilmesi, ihtiyaç duyulan nitelikli işgücünün sağlanması anlamına gelmektedir. 
Türkiye dördüncü sanayi devrimi ile birlikte teknolojik gelişmeleri, küresel ekonomide kendi lehine çevirebilmesi için ciddi bir eğitim politikası geliştirmelidir. Bu politikalar Endüstri 4.0’ın yapısına uygun bir şekilde belirlenmeli ve kararlılıkla sürdürülmelidir. Ayrıca, endüstri 4.0 ile daha da önemli hale gelen AR-GE faaliyetlerinin verimliliği için politikalar belirlenmelidir.

Endüstri 4.0 sürekli inovasyon sistemleri üzerine kuruludur. İnovasyonun yayılmasını kolaylaştırmak içinde kamu ve özel sektör iş birliği de oldukça önemlidir. Bu nedenle Türkiye de bu iş birliğini sağlayıcı adımlar atmalı ve özellikle milli politikalar oluşturularak Endüstri 4.0 altyapısı için yatırım yapılması ve okullardaki eğitim öğretim programlarının bu konuları içerecek biçimde güncellenmesi ve hemen uygulamaya geçirilmelidir. 


\section{Kaynakça}

Al, A. (2013). "Finansal Krizin İşletmelerde Muhasebe Krizi Üzerine Etkileri”, Danışman: Sinan Aslan, (Marmara Üniversitesi Sosyal Bilimler Enstitüsü: Yayınlanmamış Doktora Tezi).

Alçin, S. (2016). “Üretim İçin Yeni Bir İzlek: Sanayi 4.0”, Journal of Life Economics, 8, ss.19-30.

Avşar, Ç.T. (2016). "Sanayi 4.0 Ne Kadar Hazırız", Ekonomik Forum Dergisi, 259.

Banger, G. (2017). Endüstri 4.0 Ekstra, Ankara: Dorlion Yay.

Bauernhansl, T., Hompel M.T. \& Heuser B. V. (2014). “Industrie 4.0 in Produktion, Automatisierung und Logistik", SpringerVieweg Yay.

BBC, http://www.bbc.com/turkce/haberler-dunya-38219262 (E.T.:28.09.2017)

Blum, C. (2016). "İndüstrie 4.0: 7 Vorteile, Von Denen Wir Profitieren Werden”, www.management-circle. de/blog/indüstrie-4-0/,

Büyük, M.N \& Öz A. (2017). "Nesnelerin İnterneti ve İşletmelerin Pazarlama Faaliyetlerine Etkileri” Akademik Sosyal Araştırmalar Dergisi, 43.

Castells, M. (2013). Enformasyon Çağı: Ekonomi, Toplum ve Kültür, Cilt 3, No 1, Ağ toplumunun yükselişi, (çev.) Ebru Kılıç, İstanbul: Bilgi Üniversitesi Yay.

Çavdar, T. \& Öztürk, E. "Nesnelerin İnterneti için Yeni bir Mimari Tasarım” Sakarya Üniversitesi Fen Bilimleri Enstitüsü Dergisi, 22 (1), 39-48.

Çeliktaş, M. S., Sonlu G., Özgel S. \& Atalay, Y. (2015). "Endüstriyel Devrimin Son Sürümünde Mühendisliğin Yol Haritası”, TMMOB Makine Mühendisleri Odası Mühendis ve Makine Dergisi, 56 (662) ss. 24-34.

Duran, C. \& Saraçoğlu, M. (2009). "Yeniliğin Yaratıcılıkla Olan İlişkisi ve Yeniliğin Geliştirme Süreci”, Celal Bayar Üniversitesi İktisadi ve İdari Bilimler Fakültesi Dergisi,16 (1), 57-71.

Eğilmez, M. "Endüstri 4.0”, http://www.mahfiegilmez.com/2017/05/endustri-40.html, (E.T.:25.09.2017).

Ersoy, A.R. "Endüstri 4.0 Sürecinde Neredeyiz", http://www.endustri40. com/ endustri-4-0-surecindeneredeyiz/, (E.T.:28.09.2017)

Evans, D. (2011). “The Internet of Things How the Next Evolution of the Internet is Changing Everything”, https://www.cisco.com/c/dam/en_us/about/ac79/docs/innov/IoT_IBSG_0411FINAL.pdf (E.T.:24.09.2017)

Ghafory, I. (2017). "Siber Fiziksel Sistemler", http://www.endustri40.com/siber-fiziksel-sistemler/, (E.T.:15.09.2017).

Gilhuber, A. (2017). "Mensch-Roboter-Kollaboration-Neue Perspektive der İndustriellen Robotik", https:// www. maschinenmarkt. vogel.de/mensch-roboter-kollaboration-neue-perspektive-derindustriellen-robotik-a-641107/ (E.T.:20.12.2017)

Goasduff, L. (2015). “What is Industrie 4.0 and What Should Cios Do About It?”, https://www.gartner.com/ newsroom/id/3054921, (E.T:26.12.2017)

Gökrem, L. ve Bozuklu, M. (2016). "Nesnelerin İnterneti: Yapılan Çalışmalar ve Ülkemizdeki Mevcut Durum”, Gaziosmanpaşa Bilimsel Araştırma Dergisi, 13, 47-68.

Hermann, M., Pentek T. \& Otto B. (2015). “Design Principles for Industrie4.0 Scenarios: A Literature Review”, Technische Universität Dortmund Fakultät Maschinenbau Audi Stiftungslehrstuhl Supply Net Order Management www.snom.mb.tu-dortmund.de, S:1,

İndustrie Wegweiser, "Von Industrie 1.0 bis 4.0 - Industrie im Wandel der Zeit”, http://industrie-wegweiser. de/von-industrie-1-0-bis-4-0-industrie-im-wandel-der-zeit/ (E.T:26.12.2017)

Joint Statement on Cooperation between the Federal Ministry for Economic Affairs and Energy of the Federal Republic of Germany and the Ministry of Economy, Trade and Industry of Japan 
regarding the Internet of Things/Industrie 4.0,https://www.bmwi.de/Redaktion/DE/Downloads/ J-L/joint-statement-on-cooperation-regarding-the-internet-of-things-industrie-4-0.pdf? blob=publicationFile\&v=7, (E.T.:11.01.2018)

Kazdağli, H. (2015) “Dördüncü Sanayi Devrimi’ne Girerken İktisat Eğitimi”, Ekonomi-tek Volume, 4, (3), 9-67.

Kesayak, B. (2017). "Nesnelerin İnterneti ve Endüstriyel Uygulamaları", http://www.endustri40.com/ nesnelerin-interneti-ve-endustriyel-uygulamalari/ (E.T.:18.09.2017).

Klemp E. \& Pottebaum, J. "HandbuchIndustrie 4.0: Produktion, Automatisierung und Logistik.-"Kapitel: Additive Fertigungsverfahren im KontextvonIndustrie 4.0”, Springer Berlin Heidelberg, 2016. s.1-2

MIT Sloan Executive Education İnnovation@workBlog (2014). "The ups and downs of dynamic pricing”, https://executive.mit.edu/blog/the-ups-and-downs-of-dynamic-pricing\#.WcjnJbJJbIU, (E.T.:25.09.2017)

Mobilitat Der Zukunft, "Industrie 4.0 und ihre Auswirkungen auf die Transportwirtschaft und Logistik" ,https://mobilitaetderzukunft.at/de/publikationen/guetermobilitaet/projektberichte/ind4log4.php, (E.T.:08.01.2018)

Özdoğan, O. (2017). Endüstri 4.0 Dördüncü Sanayi Devrimi ve Endüstriyel Dönüşümün Anahtarları, İstanbul: Pusula Yay.

Raveling, J. (2017). “Die Geschichte der Digitalisierung - Teil II”, https://www.wfb-bremen.de/de/page/ stories/digitalisierung-industrie40/geschichte-der-digitalisierung-teil-zwei, (E.T:06.12.2017)

ROUSE, M. (2016). "Internet of Things(IoT)", http://internetofthingsagenda. techtarget. com/ definition/ Internet-of-Things-IoT, (E.T.: 27.11.2017).

Rudtsch, V. Gausemeier J, Gesing J., Mittag T. \& Peter, S. (2014). "Pattern-based Business Model Development Cyber-PhysicalPrdouctionSystems”, Procedia CIRP, S:25, ss.313-319.

Schwab, K. (2016). Dördüncü Sanayi Devrimi, (çev.) Zülfü Dicleli, İstanbul: Optimist Yay.

Schulze, A. (2014). "Potenziale, Chancen und Möglichkeiten durch Industrie 4.0“, http://www.flyacts.com/ blog/potenziale-chancen-und-moeglichkeiten-durch-industrie-4-0/, (E.T:30.11.2017)

Selek, A., "Endüstri Tarihine Kısa Bir Yolculuk", http://www.endustri40.com/endustri-tarihine-kisa-biryolculuk/, (E.T:26.12.2017)

Seyidoğlu, H. (2013). Uluslararası İktisat Teori Politika ve Uygulama, İstambul: Güzem Can Yay.

Soh, P. Y. ve Unkefer, H. (2014). "Industrial Internet of Things Offers Significant Oppurtunity for Growth of Digital Services, Says Accenture Report”, - https://newsroom.accenture.com/industries/systemsintegration-technology/industrial-internet-of-things-offers-significant-opportunity-for-growthof-digital-services-says-accenture-report.htm, (E.T.:23.09.2017)

Tanilli, S. (2004). Uygarlık Tarihi, İstanbul: Adam Yay.

The European Files (2017). "Industry 4.0, The new Industrial Revolution for Europe", https://www. europeanfiles.eu/magazine/industry-4-new-industrial-revolution, (E.T:30.11.2017)

The World Bank (2017). http://data.worldbank.org/, (E.T.: 28.09.2017)

TÜİK (2017). http://www.tuik.gov.tr/VeriBilgi.do (E.T.:28.09.2017) ve https://biruni.tuik.gov.tr/ gosterge/?locale=tr (E.T.:11.012018)

TÜSİAD ve BCG (2016). “Türkiye’nin Küresel Rekabetçiliği İçin Bir Gereklilik Olarak Sanayi 4.0: Gelişmekte Olan Ülke Perspektifi”, İstanbul: TUSİAD.

Ural, Ş. (1998). Bilim Tarihi, İstanbul: Kırkambar Yay.

Weckbrodt, H. (2015). "Mittelstand Darf Industrie 4.0 Nicht Vergeigen”, http://oiger.de/2015/04/15/ mittelstand-darf-industrie-4-0-nicht-vergeigen/82440, (E.T:07.12.2017)

Yazici,E. \& Düzkaya, H. (2016). “Endüstri Devriminde Dördüncü Dalga ve Eğitim: Türkiye Dördüncü Dalga Endüstri Devrimine Hazır mı?”, Eğitim ve İnsan Bilimleri Dergisi: Teori ve Uygulama, 7, 49-88. 